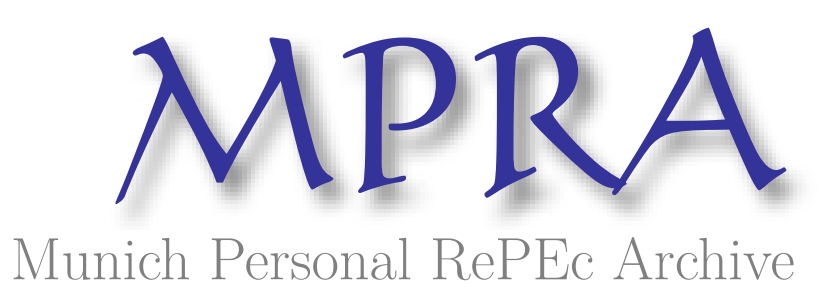

\title{
Foreign Bias in Australian Domiciled Mutual Fund Holdings
}

\author{
Mishra, Anil V \\ University of Western Sydney
}

31 January 2015

Online at https://mpra.ub.uni-muenchen.de/63376/

MPRA Paper No. 63376, posted 02 Apr 2015 01:09 UTC 


\title{
Foreign Bias in Australian Domiciled Mutual Fund Holdings
}

\author{
Anil V. Mishra \\ University of Western Sydney, School of Business, Australia
}

Corresponding author: Anil V. Mishra; University of Western Sydney, School of Business, Australia; Tel. No: +6129685 9230; E-mail address: a.mishra@uws.edu.au 


\begin{abstract}
The paper develops foreign equity bias measures for Australian domiciled mutual funds, which invest in 41 countries worldwide, over the period 2002 to 2012, by employing various models i.e. International Capital Asset Pricing, Mean-Variance, Minimum-Variance, BayesStein, Bayesian and Multi-Prior. The Bayesian measures that take into account various degrees of mistrust in ICAPM have lower values of foreign equity bias as compared to ICAPM. The Bayesian measures suggest that Australian domiciled mutual funds prefer investing in U.S., U.K., Japan and other developed countries. Paper finds that the plausible sources of foreign equity bias are GDP per capita, exchange rate volatility, foreign listing, tax credit, global financial crisis and stock market development, familiarity, institution and stock characteristic variables. There are policy implications associated with foreign bias.
\end{abstract}

Keywords: Mutual Fund, Foreign Bias, Mean-Variance, Minimum Variance, Bayes-Stein, Bayesian, Multi-Prior. 


\section{Foreign Bias in Australian Domiciled Mutual Fund Holdings}

\section{Introduction}

There is a body of literature on home bias ${ }^{1}$ that focuses on the fact that investors are found to hold disproportionately large share of their wealth in domestic portfolios as compared to predictions of standard portfolio theory. This paper focuses on foreign bias i.e. the extent to which Australian investors' underweight or overweight foreign markets in their mutual fund holdings. The paper employs Morningstar's mutual fund dataset for Australian domiciled mutual fund equity holdings in 41 developed and developing countries ${ }^{2}$ over the years 2002 to 2011 . The paper develops measures of foreign equity bias for 41 countries from Australian investors' perspective, by using various models i.e. International Capital Asset Pricing (ICAPM), Mean-Variance, Minimum-Variance, Bayes-Stein, Bayesian and Multi Prior. In this study, an Australian investor is allowed to invest in two assets, a foreign stock portfolio and the benchmark Australian market portfolio.

In the foreign equity bias studies, the actual portfolio holdings are compared to a benchmark. Depending upon the benchmark weights, there are two main approaches to foreign bias studies, i.e. model based approach and return based approach. In the model based, ICAPM, benchmark is characterized by the weight of a country in the world market capitalization $^{3}$. The ICAPM approach ignores returns. The data based approach uses time series of returns and computes benchmark weights from a mean-variance optimization ${ }^{4}$. The data based approach ignores the asset pricing $\operatorname{model}^{5}$. These two approaches give different

\footnotetext{
${ }^{1}$ See Sercu and Vanpee (2012) for a review of literature on home bias.

2 Argentina, Austria, Belgium, Brazil, Canada, Chile, China, Czech Republic, Denmark, Finland, France, Germany, Greece, Hong Kong, Hungary, India, Indonesia, Israel, Italy, Japan, Korea, Malaysia, Mexico, Netherland, New Zealand, Norway, Pakistan, Philippines, Poland, Portugal, Russia, Singapore, South Africa, Spain, Sweden, Switzerland, Taiwan, Thailand, Turkey, United Kingdom (U.K.) and United States of America (U.S.).

${ }^{3}$ Mishra (2011) develops home bias measures for Australia by considering ICAPM benchmark.

${ }^{4}$ Hasan and Simaan (2000) show that home bias is consistent with rational mean-variance portfolio choice.

${ }^{5}$ See Sharpe (1966) and Lintner (1966) for explanation of capital asset pricing model.
} 
benchmark weights and accordingly, foreign bias measures are quite different. Bayesian framework considers both, ICAPM asset pricing approach and mean-variance data based approach. It is based on investors' degree of confidence in the model based approach. As the degree of scepticism about the model grows, the portfolio weights move away from those implied by the model-based to those obtained from data based approach.

This paper makes contribution to the existing literature on Australia's equity investment abroad. First, there are no papers which specifically study foreign bias in Australian domiciled mutual fund equity holdings across a range of developed and developing countries. Second, there are papers on Australia's home bias that rely on the ICAPM approach (Mishra, 2011) and observed decision processes in superannuation funds (Warren, 2010). This is first paper which develops measures of foreign equity bias for Australia that takes into account scepticism of investors in the ICAPM model. There are few papers in the global context that employ Bayesian approach to take into account investors' scepticism in the ICAPM model (Pastor (2000), Pastor and Stambaugh (2000), Jeske (2001), Li (2004), Asgharian and Hansson (2006), Baele et al. (2007) and others). Third, the paper develops home bias measures for Australia based on Multi-Prior model's volatility correction technique introduced by Garlappi et al (2007). The Bayesian portfolio weights are more stable than data-based approach; however, there may still be extreme and volatile weights. Garlappi et al (2007) restricts the expected return for each asset to lie within specified confidence interval around its estimated value ${ }^{6}$.

Fourth, the paper develops foreign equity bias measures for Australia based on shrinkage estimation models that minimize the impact of estimation error by shrinking the sample mean toward minimum variance portfolio which improves precision associated with

\footnotetext{
${ }^{6}$ Knight (1921) states that the Bayesian decision maker is neutral to uncertainty.
} 
estimating the expected return of each asset. The improved estimation of expected returns results in improved out-of-sample performance ${ }^{7}$.

Fifth, the paper contributes to the literature on financial integration by investigating the plausible sources of Australia's foreign equity bias. In a dynamic panel setting over the period 2002 to 2011, I relate the various measures of foreign bias to six categories of variables i.e. economic development (GDP per capita, trade), stock market development (stock market capitalisation to GDP ratio, turnover, size, transaction cost), familiarity (language, distance), institution, stock characteristics (annual return, price to book ratio, price to cash flow ratio, price earnings ratio, price sales ratio) and other variables (correlation, tax credit, exchange rate volatility, foreign listing, inflation). Empirical estimation employs Arellano-Bover/Blundell-Bond linear dynamic panel-data methods to control for endogenous variables and for tests of robustness of results ${ }^{8}$. Sixth, the paper takes into account the period of global financial crisis during which cross border equity holdings fell significantly in 2008 and then recovered (only partly) in $2009^{9}$.

The paper addresses the following research questions: What are the various measures of foreign equity bias in the Australian domiciled mutual fund holdings? What are the plausible sources of foreign equity bias? What is impact of global financial crisis on foreign equity bias in Australian domiciled mutual fund holdings? Paper finds that gross domestic product per capita; stock market development, familiarity and institution variables, inflation, foreign listing real exchange rate volatility, size and global financial crisis have significant effect on foreign bias. Stock characteristics i.e. annual return, price to book ratio, price to

\footnotetext{
${ }^{7}$ See Stein (1955), Berger (1974), Gorman and Jorgensen (2002), Herold and Maurer (2003), Ledoit and Wolf (2003), Wang (2005), Zellner (2010) for shrinkage approach.

${ }^{8}$ Ahearne et al. (2004) and Chan et al. (2005) use pure cross-sectional analysis.

${ }^{9}$ UK foreign equity holdings were US \$ 1508710 million in 2007, which fell to US \$ 824018.5 million in 2008 and partly recovered to US \$ 1079254 million in 2009. US equity holdings abroad were US \$ 5247983 million in 2007, which fell to US \$ 2748428 million in 2008 and partly recovered to US\$ 3995298 million in 2009.
} 
cash flow ratio, price earnings ratio and price sales ratio are found to have a significant impact on foreign bias.

The next section discusses literature review. Section 3 gives overview of Australian domiciled mutual fund holdings and discusses various foreign bias and optimal portfolio weight models. Section 4 describes data and variables. Section 5 discusses validity of ICAPM and discusses foreign bias measures. Section 6 discusses methodology and empirical results and finally section 7 concludes.

\section{Literature Review}

The literature on home bias revolves around different motives of investors, including information asymmetries, behavioural biases, hedging motives and explicit barriers to international investment. Several research papers have considered the effect of indirect barriers, such as information asymmetries, on equity investment and home bias. French and Poterba (1991) use a simple model of investor preferences and behaviour to show that current portfolio patterns imply that investors in each nation expect returns in their domestic equity market to be several hundred basis points higher than returns in other markets. Tesar and Werner (1995) state that there is a strong evidence of a home bias in national investment portfolios despite the potential gains from international diversification. Coval and Moskowitz (1999) state that portfolios of domestic stocks exhibit a preference of investing close to home. Huberman (2001) states that shareholders of a Regional Bell Operating Company (RBOC) tend to live in the area which it serves, and an RBOC's customers tend to hold its shares rather than other RBOCs' equity. People invest in the familiar while often ignoring the principles of portfolio theory. Chan et al. (2005) find robust evidence that mutual funds, in aggregate, allocate a disproportionately larger fraction of investment to domestic stocks. Campbell and Kraussl (2007) state that due to greater downside risk, investors may think globally, but instead act locally and their model's results provide an alternative view of the 
home bias puzzle. Barron and Ni (2008) link the degree of home bias across portfolio managers to portfolio size. Nieuwerburgh and Veldkamp (2009) state that investors profit more from knowing information others do not know and learning amplifies information asymmetry. Mondria and $\mathrm{Wu}$ (2010) state that home bias increases with information capacity and decreases with financial openness. Coeurdacier and Rey (2013) review various explanations of home bias puzzle highlighting recent developments in macroeconomic modelling that incorporate international portfolio choices in standard two-country general equilibrium models.

Coen (2001) and Pesenti and Wincoop (2002) focus on non-tradables effect on home bias. Strong and Xu (2003), Suh (2005) and Lutje and Menkhoff (2007) focus on behavioral explanation of home bias. There are some papers that link corporate governance and home bias (Dahlquist et al., 2003; Kho et al., 2009). There are some studies on explicit barriers to international investment and home bias including Glassman and Riddick (2001) and Moor et al (2010).

\section{Foreign Bias Measure and Optimal Portfolio Weight Models}

\subsection{Australian Domiciled Mutual Fund Holdings and Foreign Bias Measure}

Home bias is a situation where an investor holds far too high a share of their wealth in domestic equities compared with the optimal share predicted by the theory of portfolio choice. Foreign bias is the relative difference between actual foreign holdings of a country $\left(w_{i j}\right)$ and optimal foreign weights $\left(w_{j}^{*}\right)$.

$$
\begin{aligned}
& F B_{i}=\log \left(\frac{w_{i j}}{w_{j}^{*}}\right) \\
& w_{i j}=\frac{M V_{i j}}{\sum_{j=1}^{41} M V_{i j}}
\end{aligned}
$$


where $w_{i j}$ is the share of country $j$ in Australian domiciled mutual fund holdings $i$.

Optimal portfolio weights $\left(w_{j}^{*}\right)$ are calculated by employing various methodologies including classical mean-variance, international capital asset pricing model, minimum variance portfolio, Bayes-Stein shrinkage portfolio model, Bayesian portfolio model and Multi-Prior portfolio model.

The weight of country $j$ in the world market portfolio of sample 41 countries is computed as:

$$
w_{j}^{*}=\frac{M V_{j}^{*}}{\sum_{i=1}^{41} M V_{i}^{*}}
$$

where $w_{j}^{*}$ is the share of country $j$ in the world market portfolio and $M V_{j}^{*}$ is the market capitalization of country $j$.

\section{[Table 1]}

The paper employs Morningstar's mutual fund equity holdings dataset for a sample of 1414 Australian domiciled mutual funds holdings in 41 developed and developing countries over the years 2002 to 2011. Table 1 presents distribution of Australian average equity mutual fund allocations (in percentage) across 41 markets worldwide ${ }^{10}$. Column (1) illustrates that the average market capitalization of Australian domiciled mutual fund holdings in the United States is about US\$ 28501 million and in the United Kingdom is approximately US\$ 8446 million. Column (2) illustrates percentage ratio of average allocation of Australian domiciled mutual fund holdings to total allocation of Australian domiciled mutual fund holdings across 41 countries. The mutual fund allocation is about $13.79 \%$ in the United

\footnotetext{
${ }^{10}$ The number of Australian domiciled mutual funds investing in US are 86, Japan (56), UK (71), France (54), Germany (51), Canada (59), Switzerland (51), New Zealand (38), Netherlands (52), China (53), Hong Kong (61), Korea (39), Italy (41), Spain (27), Brazil (41), Singapore (42), Finland (35), Taiwan (64), Sweden (34), South Africa (42), India (34), Belgium (32), Norway (38), Thailand (28), Denmark (32), Austria (31), Mexico (27), Russia (18), Israel (25), Malaysia (27), Greece (23), Indonesia (18), Turkey (14), Portugal (14), Philippines (12), Argentina (7), Hungary (15), Chile (4), Poland (9), Czech Republic (3), Pakistan (6).
} 
States, followed by Japan (6.85\%) and the United Kingdom (3.85\%). Column (3) presents average world market capitalization weight of countries. The share of Australian domiciled mutual fund holdings in Australia (62.78\%) is much higher compared to its average world market capitalization weight of $2.20 \%$. The United States has the highest average world market capitalization weight of $38.36 \%$.

\subsection{Optimal Portfolio Weight Models}

\subsubsection{Classical Mean-Variance Portfolio Model:}

In the classical Markowitz (1952), mean-variance model; investor maximizes expected utility

$$
\max _{w} w^{\prime} \mu-\frac{\gamma}{2} w^{\prime} \sum w
$$

where $w$ is the optimal portfolio of $N$ risky assets, $\mu$ is the $N$ - vector of expected excess returns over the risk-free asset, $\sum$ is the $N$ x $N$ covariance matrix, $\gamma$ is the risk aversion parameter. Under the assumption $w^{\prime} 1_{N}=1$, when a risk-free rate is available and chosen as the zero-beta portfolio and when short sales are allowed,

$$
w^{*}=\frac{\sum^{-1} \mu}{1_{N}^{\prime} \Sigma^{-1} \mu}
$$

The computation of $w^{*}$ involves the expected excess returns and covariance matrix of returns. Expected returns are difficult to estimate. In computation of weights in (5), the expected excess returns are based on historical data. Merton (1980) states that expected return estimates based on historical data are very unreliable due to high volatility of returns ${ }^{11}$.

\subsubsection{Minimum Variance Portfolio}

The minimum variance portfolio is leftmost portfolio of the mean variance efficient frontier and it has a unique property that security weights are independent of expected returns on the

\footnotetext{
11 See Hodges and Brealey (1978), Michaud (1989), Best and Grauer (1991), Chopra and Ziemba (1993), Britten Jones (1999) and Jeske (2001), Litterman (2003) for discussion on mean variance optimal portfolios.
} 
individual securities. Suppose there are $N$ assets having a variance-covariance matrix $\sum$. The minimum variance portfolio weight as per Merton (1973) is

$w=\frac{I \cdot \sum^{-1}}{I \cdot \sum^{-1} \cdot I^{\prime}}$

where $\sum$ is variance-covariance matrix of returns, $I$ is a $\mathrm{N}$-dimensional vector of 1 .

\subsubsection{Bayes-Stein Shrinkage Portfolio Model}

In the Bayes-Stein shrinkage approach, the sample mean is shrunk to mean of the minimumvariance portfolio $^{12}$.

The Bayes-Stein estimate of expected return is

$$
E\left[R_{B S}\right]=(1-\psi) \cdot \bar{R}+\psi \cdot . R_{M I N} \cdot I
$$

The Bayes-Stein variance-covariance matrix is

$$
\sum_{B S}=\sum \cdot\left(1+\frac{1}{T+\lambda}\right)+\frac{\lambda}{T(T+1+\lambda)} \cdot \frac{I . I^{\prime}}{I^{\prime} \sum^{-1} I}
$$

where $\bar{R}$ is the vector of historical mean returns, $R_{M I N}$ is the minimum variance portfolio return, $\sum$ is the variance covariance matrix based on historical returns, $I$ is vector of ones.

$\lambda$ is computed as

$$
\lambda=\frac{(N+2)(T+2)}{\left(\bar{R}-R_{M I N} \cdot I\right) \cdot \Sigma^{-1} \cdot\left(\bar{R}-R_{M I N} \cdot I\right) \cdot(T-N-2)}
$$

where $N$ is the number of return observations, $T$ is the number of domestic market portfolios.

The shrinkage factor ${ }^{13} \psi$ is

$$
\psi=\lambda / T+\lambda
$$

\subsubsection{International Capital Asset Pricing Model}

\footnotetext{
${ }^{12}$ Zellner and Chetty (1965) utilize a Bayesian approach to analyse several prediction and decision problems associated with normal regression models. See Jorion $(1985,1986)$ for Bayes-Stein estimation.

${ }^{13}$ The shrinkage approach states that a Bayesian investor, facing uncertainty about an asset-pricing model, assigns a weight between the unrestricted estimate and the estimate restricted by the asset-pricing model. The weight is the shrinkage factor (Wang, 2005).
} 
The traditional international capital asset pricing model (ICAPM) predicts that an investor should hold equities from a country as per that country's share of world market capitalization (Lintner, 1965). ICAPM is model based approach.

$R_{D}-R_{F}=\beta+\beta_{A}\left(R_{A}-R_{F}\right)+\varepsilon$

where $R_{D}$ is the return on the foreign market portfolio, $R_{F}$ is the risk-free rate, $R_{A}$ is the return on the Australian stock market portfolio, $\beta_{A}$ is beta of the domestic Australian market, $\beta$ is the intercept and $\varepsilon$ is the error term.

The ICAPM model is valid if the estimates of the intercept $\hat{\beta}$, are zero. An intercept different from zero, even if insignificant will lead to mis-trust in the prediction of ICAPM.

\subsubsection{Bayesian Mean-Variance Portfolio Model}

$y_{i}=\beta_{1}+\beta_{2} x_{i 2}+\ldots \ldots \ldots \ldots \ldots \ldots \ldots+\beta_{k} x_{i k}+\varepsilon_{i}$

where $y$ and $\varepsilon$ are $N X 1$ vectors, $\beta$ is $k X 1$ vector, $X$ is $N X k$ matrix.

In the matrix notation,

$y=X \beta+\varepsilon$

The ICAPM is valid if the estimates of the intercept, $\hat{\beta}$, are zero and an investor fully trusts ICAPM. The degree of trust is expressed in values of standard errors of the intercept $\sigma_{\beta}$. A small value of $\sigma_{\beta}$ indicates a strong belief that ICAPM model is valid and optimal portfolio weights are closer to those of ICAPM. A higher value of $\sigma_{\beta}$ indicates a dis-belief in the model based ICAPM approach and portfolio weights are closer to data-based mean variance approach. Full mis-trust in the model results in optimal weights that correspond to data-based optimal weights. 


\section{(i) The Prior ${ }^{14}$}

In the Bayesian analysis, there is prior (non-data) belief in the model i.e. the belief in a zero intercept and no mispricing. The prior is updated using returns data to a certain extent depending on the chosen degree of mistrust in the model. The sample mispricing $\beta$, is shrunk accordingly towards the prior mean of $\beta$ to obtain the posterior mean of $\beta$.

I use a natural conjugate prior, ${ }^{15}$

$$
p(\beta, h)=p(\beta) p(h)
$$

where $p(\beta, h)$ is a Normal density and $p(h)$ is a Gamma density.

$$
\begin{aligned}
& p(\beta)=\frac{1}{(2 \pi)^{\frac{k}{2}}}|\underline{V}|^{-\frac{1}{2}} \exp \left[-\frac{1}{2}(\beta-\underline{\beta})^{\prime} \underline{V}^{-1}(\beta-\underline{\beta})\right] \\
& p(h)=c_{G}^{-1} h^{\frac{\underline{v}-2}{2}} \exp \left(-\frac{h \underline{v}}{2 \underline{s}^{-2}}\right)
\end{aligned}
$$

where $\underline{V}$ is a $k X k$ is a positive definite prior covariance matrix, $\underline{v}$ is degrees of freedom, $\underline{s}^{2}$ is standard error, error precision $h=\frac{1}{\sigma^{2}}, c_{G}$ is integrating constant for the Gamma probability density function.

\section{(ii) The Posterior}

The posterior is proportional to prior times the likelihood.

$$
p(\beta, h \mid y) \alpha\left\{\exp \left[-\frac{1}{2}\left\{h(y-X \beta)^{\prime}(y-X \beta)+(\beta-\underline{\beta})^{\prime} \underline{V}^{-1}(\beta-\underline{\beta})\right\}\right] h^{\frac{N+\underline{v}-2}{2}} \exp \left[-\frac{h \underline{v}}{2 \underline{s}^{-2}}\right]\right.
$$

Upon performing calculations,

$$
\begin{aligned}
& p(\beta, h \mid y) \alpha \exp \left[-\frac{1}{2}(\beta-\bar{\beta})^{\prime} \bar{V}^{-1}(\beta-\bar{\beta})\right] \\
& \beta \mid y, h \sim N(\bar{\beta}, \bar{V})
\end{aligned}
$$

From (17) as a function of $h$,

\footnotetext{
${ }^{14}$ Pastor (2000) states that his Bayesian methodology allows the investor to include prior information about the residual covariance matrix of asset returns. By simply increasing the degrees of freedom in the prior distribution of the residual covariance matrix, the sample matrix can be shrunk arbitrarily to a matrix specified a priori.

${ }^{15}$ Refer Koop (2003) for details.
} 
$p(h \mid y, \beta) \alpha h^{\frac{N+\underline{v}-2}{2}} \exp \left[-\frac{h}{2}\left\{(y-X \beta)^{\prime}(y-X \beta)+\underline{v s}^{2}\right\}\right]$

$h \mid y, \beta \sim G\left(\bar{s}^{-2}, \bar{v}\right)$

where

$\bar{v}=N+\underline{v}$

and

$$
\bar{s}^{2}=\frac{(y-X \beta)^{\prime}(y-X \beta)+\underline{v s}^{2}}{\bar{v}}
$$

Posterior simulator called the Gibbs sampler uses conditional posteriors (19) and (21) to produce random draws, $\beta^{(s)}$ and $h^{(s)}$ for $\mathrm{s}=1,2 \ldots \ldots \ldots \ldots . . . \mathrm{S}$, which can be averaged to produce estimates of posterior properties.

\section{(iii) The Gibbs Sampler}

Let $\theta$ be a $p$ - vector of parameters and $p(y \mid \theta), p(\theta)$ and $p(\theta \mid y)$ are the likelihood, prior and posterior, respectively. Gibbs sampler chooses a starting value, $\theta^{(0)}$. For $s=1, \ldots \ldots \ldots \ldots \ldots . . . . .$, take a random draw $\theta_{(1)}^{(s)}$ from $p\left(\theta_{(1)} \mid y, \theta_{(2)}^{(s-1)}, \theta_{(3)}^{(s-1)}, \ldots \ldots \ldots \ldots . . ., \theta_{(B)}^{(s-1)}\right), \theta_{(2)}^{(s)}$ from $p\left(\theta_{(2)} \mid y, \theta_{(1)}^{(s)}, \theta_{(3)}^{(s-1)}, \ldots \ldots \ldots \ldots . ., \theta_{(B)}^{(s-1)}\right) \ldots \ldots \theta_{(B)}^{(s)} \quad$ from $\quad p\left(\theta_{(B)} \mid y, \theta_{(1)}^{(s)}, \theta_{(2)}^{(s)}, \ldots \ldots \ldots \ldots . ., \theta_{(B-1)}^{(s)}\right)$. Following the steps will yield a set of $S$ draws, $\theta^{(s)}$ for $s=1$ $S$. Drop the first $S_{0}$ of these to eliminate the effect of $\theta^{(0)}$ and average the remaining draws to create estimates of posterior. In our empirical estimation, I discard an initial $S_{0}=1000$ burn-in replications and include $S_{1}=10000$ replications.

Gibbs sampling provides a function $\hat{g} s_{1}$,

$$
\hat{g} S_{1}=\frac{1}{S_{1}} \sum_{s=S_{0}+1}^{S} g\left(\theta^{(s)}\right)
$$

As $S_{1}$ goes to infinity, $\hat{g} s_{1}$ converges to $E[g(\theta) \mid y]$.

\section{(iv) Prediction and Optimal weights}

The predictive density is calculated as

$$
p\left(y^{*} \mid y\right)=\iint p\left(y^{*} \mid y, \beta, h\right) p(\beta, h \mid y) d \beta d h
$$


I employ different degrees of mistrust in the ICAPM by employing different standard errors of intercept and compute optimal weights.

The Bayesian mean-variance optimal weights are computed as:

$$
w^{*}=\frac{\sum^{*-1} \mu^{*}}{1_{N}^{\prime} \sum^{*-1} \mu^{*}}
$$

where $\mu^{*}$ is predictive mean and $\sum^{*-1}$ is variance obtained from Bayesian approach.

\subsubsection{Bayesian Multi-Prior Approach}

Garlappi et al (2007) impose an additional constraint on the mean-variance portfolio optimization that restricts the expected return for each asset to lie within a specified confidence interval of its estimated value, and introduce an additional minimization over the set of possible expected returns subject to the additional constraint.

Upon imposing above restrictions, the mean variance model becomes

$$
\max _{w} \min _{\mu} w^{\prime} \mu-\frac{\gamma}{2} w^{\prime} \sum w
$$

subject to $f(\mu, \hat{\mu}, \Sigma) \leq \varepsilon$

and $w^{\prime} 1_{N}=1$

In equation (28), $f($.$) is a vector-valued function that characterizes the constraint and \varepsilon$ is a vector of constants the reflects both the investor's ambiguity and his aversion to ambiguity.

The optimal portfolio is given by,

$$
w^{*}=\frac{\sigma_{p}^{*}}{\sqrt{\chi}+\gamma \sigma_{p}^{*}} \sum^{-1}\left[\hat{\mu}-\frac{1}{A}\left(B-\frac{\sqrt{\chi}+\gamma \sigma_{P}^{*}}{\sigma_{P}^{*}}\right) 1_{N}\right]
$$

where

$$
\chi=\varepsilon \frac{(T-1) N}{T(T-N)}
$$

$T$ is the number of observations in our sample and $N$ is the number of assets.

$$
\begin{aligned}
& A=1_{N}^{T} \Sigma^{-1} 1_{N} \\
& B=\hat{\mu}^{\prime} \Sigma^{-1} 1_{N} \\
& C=\hat{\mu}^{\prime} \Sigma^{-1} \hat{\mu}
\end{aligned}
$$


$\sigma_{p}^{*}$ is positive real root obtained from the following equation,

$A \gamma^{2} \sigma_{p}^{4}+2 A \gamma \sqrt{\chi} \sigma_{p}^{3}+\left(A \chi-A C+B^{2}-\gamma^{2}\right) \sigma_{p}^{2}-2 \gamma \sqrt{\chi} \sigma_{p}-\chi=0$

The optimal portfolio of an investor who is averse to parameter uncertainty can also be

written as

$w_{A A}(\varepsilon)=\phi_{A A}(\varepsilon) w_{M I N}+\left[1-\phi_{A A}(\varepsilon)\right] w_{M V}$

where

$\phi_{A A}(\varepsilon)=\frac{\sqrt{\varepsilon \frac{(T-1) N}{T(T-N)}}}{\gamma \sigma_{p}^{*}+\sqrt{\varepsilon \frac{(T-1) N}{T(T-N)}}}$

$w_{M I N}=\frac{1}{A} \sum^{-1} 1_{N}$

$w_{M I N}$ is the minimum variance portfolio weights.

$w_{M V}=\frac{1}{\gamma} \Sigma^{-1}\left(\mu^{\prime}-\hat{\mu}_{0} 1_{N}\right)$

$w_{M V}$ is the mean-variance portfolio weights formed using maximum likelihood estimates of expected return.

The optimal portfolio of an investor who is averse to parameter uncertainty ${ }^{16}$ can also be written as

$w_{A A}(\varepsilon)=\phi_{A A}(\varepsilon) w_{M I N}+\left[1-\phi_{A A}(\varepsilon)\right] w_{B S}$

where

$w_{B S}$ is the Bayes Stein portfolio weights.

\section{Data and Variables}

\subsection{Data}

In this study, an Australian investor is allowed to invest in two assets, a foreign stock portfolio and the benchmark Australian market portfolio. I employ weekly MSCI Australian

\footnotetext{
${ }^{16}$ Wang (2005) employs a shrinkage approach to examine the empirical implications of aversion to model uncertainty.
} 
\$ denominated returns for 41 foreign countries $^{17}$ and benchmark Australian stock market index over the period from January 1996 to December $2011^{18}$. The weekly risk-free rate is Australian \$ weekly deposit rate. I calculate actual foreign equity holdings of Australian domiciled mutual funds in 41 foreign countries. As a robustness check, I also calculate actual foreign equity holdings based on foreign portfolio assets and liabilities reported in IMF's Coordinated Portfolio Investment Survey (CPIS) dataset ${ }^{19}$. Market capitalization data is from Standard and Poor's (2012).

\section{[Table 2]}

\subsection{Variables that influence home bias:}

I employ various determinants of home bias from standard literature. These determinants can be classified into six categories: (i) economic development; (ii) stock market development; (iii) familiarity; (iv) institution; (v) other variables; and (vi) stock characteristics. Table 2 illustrates average values of explanatory variables over the period from 2002 to 2011.

\section{A. Economic Development}

I employ two measures of economic development i.e. log value of gross domestic product per capita (GDPPC); log value of average of exports and imports scaled by GDP (TR). The data on GDPPC and TR is from World Development Indicators (2012).

GDP per capita may influence a country's tendency to engage in international asset trade. Higher income per capita is associated with lower risk aversion and the international asset trade is perceived as riskier than domestic trade; this may also raise international asset trade.

\footnotetext{
17 Argentina, Austria, Belgium, Brazil, Canada, Chile, China, Czech Republic, Denmark, Finland, France, Germany, Greece, Hong Kong, Hungary, India, Indonesia, Israel, Italy, Japan, Korea, Malaysia, Mexico, Netherland, New Zealand, Norway, Pakistan, Philippines, Poland, Portugal, Russia, Singapore, South Africa, Spain, Sweden, Switzerland, Taiwan, Thailand, Turkey, U.K. and U.S.

${ }^{18}$ I also employ monthly MSCI US \$ denominated returns for 41 countries and benchmark Australian stock market over the period from January 1996 to December 2011 and construct home bias measures.

${ }^{19}$ http:cpis.imf.org/Default.aspx
} 
The participation in foreign asset markets involve fixed costs; this may provide a reason why high income level countries' involve more in international asset trade. Table 2 illustrates that Norway has the highest GDPPC (11.12), followed by Switzerland (10.91) and Denmark (10.78).

Trade is sum of exports and imports of goods and services measured as a share of gross domestic product. Lane and Milesi-Ferreti (2008) state that bilateral equity investment is strongly correlated with the underlying patterns of trade in goods and services. Table 2 illustrates that the country with highest TR is Singapore (1.37), followed by Hong Kong (1.30).

\section{B. Stock Market Development}

Generally, investors prefer holding stocks in more developed stock markets because of higher liquidity and lower transaction costs in these markets. I employ four measures of stock market development i.e. log value of ratio of stock market capitalization to GDP (SMCAP); log value of ratio of total value of shares traded during the period to market capitalization during the period (TURN); foreign country's share of world market capitalization (SIZ) and log value of foreign country's transaction cost (TRAN). SMCAP is a proxy for equity market development. Levine and Zervos (1998) state that more developed financial markets are generally more diversified and better integrated with world financial markets than smaller markets and hence likely to share information more intensively. SMCAP is highest for HK (1.39) followed by Switzerland (0.77). The turnover ratio (TURN) measures trading relative to size of economy (Demirguc-Kunt and Levine, 1996). TURN is highest for Korea (0.74) followed by US (0.63). The data of SMCAP and TURN is from World Development Indicators (2012). SIZ tests the assumption of traditional theory of ICAPM that investors should diversify according to their country's share of world market capitalization. SIZ is highest for US (39.53), followed by Japan (8.92) and UK (6.71). The 
data on stock market capitalization is from Standard and Poor's (2012). Home bias could arise due to high transaction costs associated with trading foreign equities. The transaction cost data is derived from Elkins McSherry Co (www.elkins-mcsherry.com). The transaction cost comprises of three cost components i.e. commissions, fees and market impact cost. The paper takes into account total cost comprising of all three cost components. TRAN is lowest for Japan (-1.70), followed by US (-1.65) and Germany (-1.45).

\section{Familiarity}

Coval and Moskowitz (1999), Huberman (2001), Grinblatt and Keloharju (2001) and Sarkissian and Schill (2004) state that familiarity plays an important role in investors' equity investment decisions. I employ two measures of familiarity: Language (LAN) dummy=1 if foreign country's language is English otherwise 0 and logarithm of distance (DIS) in kilometres between capital city of Australia and capital city of foreign country. Countries such as US, UK, Canada, NZ and Australia share English as a common language while countries such as China, Italy, Japan, Korea, Sweden, Switzerland, and Germany have their own languages. Investors prefer to invest in foreign countries that share a common language with their home country. Common language may better enable investors to read company financial reports and financial press analysis. This may enhance investors' familiarity with destination countries financial system and thus reduce investors' information costs. The data on language is from CIA (2012). DIS is lowest for New Zealand (3.36) and highest for Portugal $(4.25)^{20}$.

\section{Institution}

The paper employs two measures of institution i.e. QUA is log value of average of World Bank governance indicators $^{21}$ (rule of law, control of corruption, regulatory quality and

\footnotetext{
${ }^{20}$ The source of data for distance is http://www.timeanddate.com/worldclock/distance.html.

${ }^{21}$ www.govindicators.com
} 
government effectiveness) and LEG is legal dummy=1 if foreign country has common law system otherwise 0.

Rule of law reflects perceptions of the extent to which agents have confidence in and abide by the rules of society, and in particular the quality of contract enforcement, property rights, the police, and the courts, as well as the likelihood of crime and violence. Control of corruption reflects perceptions of the extent to which public power is exercised for private gain, including both petty and grand forms of corruption, as well as "capture" of the state by elites and private interests. Regulatory quality reflects perceptions of the ability of the government to formulate and implement sound policies and regulations that permit and promote private sector development. Government effectiveness reflects perceptions of the quality of public services, the quality of the civil service and the degree of its independence from political pressures, the quality of policy formulation and implementation, and the credibility of the government's commitment to such policies. QUA is highest for Denmark (0.74), followed by Finland (0.72) and Singapore (0.67).

Information advantages may arise due to similarity of institutions and legal structures. Legal rights of investors differ across countries, primarily due to legal origin. This applies to commercial laws for financing of firms, for investment and also for law enforcement (La Porta et al, 1997; 1998). Countries can be classified as per German, French, Scandinavian civil law families, the English common law and the Socialist law family to account for reduced information asymmetries between countries belonging to the same legal origin. U.S., U.K., New Zealand, India and Australia have common law system.

\section{E. Other Variables}

The paper employs other control variables i.e. COR is correlation of monthly returns of Australia and monthly returns of foreign country over the years 1995 to 2011. Tax credit (TX) is product of foreign dividend tax withheld rate and dividend yield if foreign dividend 
tax withheld rate is less than or equal to home country's combined corporate income tax rate. It is product of home country's combined corporate income tax rate and foreign dividend yield if foreign dividend tax withheld rate is greater than home country's combined corporate income tax. Exchange rate volatility (VL) is logarithm of standard deviation of monthly real exchange rate changes over the period 1995 to 2011. Foreign listing (FL) is logarithm of share of global stock market that is listed on source country's stock exchanges (either directly or has issued public debt in the source country). Inflation (INFL) is annual percentage change in consumer price index.

The correlation coefficient is a proxy for benefits of diversification between Australia and foreign country. When the correlation coefficient is small, Australian investors enjoy a larger diversification gain from investing in a foreign country. The correlation coefficient (COR) between Australian and Canada is 0.74 , followed by South Africa (0.73) and Norway (0.72). The monthly returns are calculated from MSCI monthly index data.

Tax credit on taxes paid by Australian investors on their foreign dividends, avoids double taxation. Mishra (2014) states that tax credit variable for foreign taxes paid on dividends is found to have a statistically significant impact on home bias ${ }^{22}$. The foreign dividend tax withheld rate is 0 for U.K., H.K. and Singapore. Therefore, tax credit for U.K., H.K. and Singapore is 0 . The tax data is from Price Waterhouse.

Real exchange rate volatility induces a bias towards domestic financial assets because it puts additional risk on holding foreign securities, from a domestic currency investor's perspective, unless foreign local currency real returns and the real exchange rate are sufficiently negatively correlated. Mishra (2011) finds that Australians invest significantly less in a country if the real exchange rate volatility of that country is relatively high. VL for New Zealand is lowest (-3.87).

\footnotetext{
${ }^{22}$ Refer Mishra (2014) for formulation of tax credit variable.
} 
When foreign countries' firms list equity on source country's stock exchanges or issue public debt in source country's markets, barriers to source country's investors are reduced. Ahearne et al (2004) state that foreign countries whose firms do not alleviate information costs by opting into the US regulatory environment are more severely underweighted in US equity portfolios. FL for U.S. is highest (-1.80), followed by U.K. (-2.63) and Japan (-2.84). Infact, these are the top three destinations for Australia's cross border equity holdings.

Inflation rate is proxy for the macroeconomic stability. High level of inflation rate means low level of economic stability which influences the decision of foreign investors. INFL for Japan is lowest (0.34), followed by Switzerland (0.72).

Australia’s global foreign equity investment fell from US \$ 263,672 million in 2007 to US \$ 157,943 million in 2008 and recovered partly US \$244,825 million in $2009^{23}$. Global Financial Crisis (GFC) is a dummy=1 for 2008 during global financial crisis otherwise 0.

\section{F. Stock Market Characteristics ${ }^{24}$}

The paper employs various stock market characteristic variables i.e. Annual return (AR) is logarithm of annualized return of fund; Price Book ratio (PB) is weighted average of the price to book ratios of all stocks in a portfolio; Price Cash flow ratio (PC) is the weighted average of the price to cash-flow ratios of the stocks in a portfolio; Price Earnings ratio (PE) is weighted average of the price to earnings ratios of the stocks in a portfolio; Price Sales ratio (PS) represents the weighted average of the price to sales ratios of the stocks in a portfolio.

Annual return represents shareholders' gains during the stated calendar year. Total return includes both unrealized capital gains and losses (the increase or decrease in share price) and any dividend distributions. It is calculated by taking the change in the stock's

\footnotetext{
${ }^{23}$ In 2007, Australia's foreign equity investment in U.S. was US \$ 115,704 million, in 2008 (US \$ 72,935 million) and in 2009 (US \$ 102,473 million). Again, in 2007, Australia's foreign equity investment in U.K. was US \$ 25,174 million, in 2008 (US \$14,150 million) and in 2009 (US \$23,521 million).

${ }^{24}$ See Gompers and Metrick (2001), Dahlquist and Robertsson (2003) for institutional investment and stock characteristics.
} 
price, reinvesting all dividends, dividing by the initial price, and expressing the result as a percentage. Australian domiciled funds investing in Czech Republic have the lowest average AR of -3.36 , followed by those investing in Poland (-3.17) and Israel (-3.01). Australian domiciled funds investing in U.S. have the highest average AR of -2.12 , followed by those investing in U.K. (-2.14).

Price Book ratio of a company is calculated by dividing the market price of its stock by the company's per-share book value. A high price book ratio indicates that the price of the stock exceeds the actual worth of the company's assets, while a low price book ratio indicates that the stock is a bargain. Australian domiciled funds investing in New Zealand have average PB of 1.03 and those investing in U.S. have average PB of 0.94.

Price cash flow ratio represents the amount an investor is willing to pay for a dollar generated from a particular company's operations. Price cash flow ratio shows the ability of a business to generate cash and acts as a gauge of liquidity and solvency. Australian domiciled funds investing in New Zealand have average PC of 2.31 and those investing in U.S. have average $\mathrm{PC}$ of 2.25 .

Price earnings ratio of a stock is calculated by dividing the current price of the stock by its trailing 12 months' earnings per share. In computing the average, Morningstar weighs each portfolio holding by the percentage of equity assets it represents, so that larger positions have proportionately greater influence on the final price earnings ratio. Australian domiciled funds investing in Sweden have average PE of 2.81 and those investing in Norway have average PE of 2.80 .

Price sales ratio is a stock's current price divided by its sales per share over the trailing 12 months. Price sales ratio represents the amount an investor is willing to pay for a dollar generated from a particular company's operations. Australian domiciled funds 
investing in US have average PS of 0.44. Appendix Table A.1 illustrates the data sources of variables.

\section{Validity of ICAPM and Foreign Bias Measures}

\subsection{Validity of ICAPM}

Previous studies on Australia's foreign equity investment employ traditional home bias measure based on the ICAPM ${ }^{25}$. The traditional model based ICAPM, predicts that an investor should hold equities from a country as per that country's share of world market capitalization. In this section, I test the credibility of model by conducting tests of ICAPM model for each country.

\section{[Table 3]}

Table 3 illustrates the OLS regressions results for equation $(11)^{26}$. Alphas are positive and significant in 2 countries. Alphas are positive and insignificant in 20 countries. Positive alphas make domestic investment more attractive to domestic investors who have incomplete trust in the ICAPM and lead to lower equity home bias measures. 19 countries have negative and insignificant alphas indicating investors to take a domestic position that is lower than the country's weight in the global market portfolio. Standard errors of alphas range from 0.25 (US) to 1.20 (Russia). In the Bayesian approach, I take standard errors on the alphas as degree of mistrust in the ICAPM. A high degree of mistrust implies the optimal weights will deviate more from ICAPM, towards data based mean variance framework. In the following section, I present the home bias measures using various approaches.

\subsection{Foreign Bias Measures}

\section{[Table 4]}

\footnotetext{
${ }^{25}$ Mishra (2011).

${ }^{26}$ I use weekly data from January 5, 1995 to December 28, 1995 for each country to compute the Bayesian prior information.
} 
Table 4 illustrates the average foreign bias measures (2002 to 2011) using various approaches i.e. ICAPM ${ }^{27}$; classical Mean-Variance; Minimum-Variance; Bayes-Stein; Bayesian for various standard errors of alpha intercept (country specific standard errors , $0.25,0.5,1.2)$; Multi-Prior correction to data based approach; Multi-Prior correction to bayes-stein approach and Multi-Prior correction to Bayesian approach for various standard errors of alpha intercept (country specific standard errors , 0.25, 0.5, 1.2). Foreign bias is calculated as per equation (1), log ratio of $w_{i j}$ to $w_{j}^{*}$. Optimal portfolio weights $\left(w_{j}^{*}\right)$ are calculated by employing various methodologies including classical mean-variance, international capital asset pricing model, minimum variance portfolio, Bayes-Stein shrinkage portfolio model, Bayesian portfolio model, Multi-Prior portfolio model as explained in section 3.2 .

In column (1), ICAPM average foreign bias measure indicates that Australian domiciled mutual funds prefer investing in New Zealand and Finland. Column (2) indicates data-based Mean-Variance measure of foreign bias. Australian domiciled mutual funds are found to underinvest in Hungary, Pakistan, Poland, Chile and Argentina. On the other hand, Australian domiciled mutual funds prefer investing in France, U.S., Japan, Switzerland and Hong Kong.

Column (3) illustrates the Minimum-Variance foreign bias measure in which individual security weights are independent of expected returns. Column (4) computes MultiPrior return based home bias measures for an investor who is averse to parameter uncertainty and whose optimal portfolio weights are based on Minimum-Variance and Mean-Variance as per equation (36). Column (5) illustrates the Bayes-Stein home bias measures. Column (6) computes Multi-Prior return based home bias measures for an investor who is averse to parameter uncertainty and whose optimal portfolio weights are based on Minimum-Variance

\footnotetext{
${ }^{27}$ I also construct home bias measures based on Bekaert and Wang (2009), Solnik and Zuo (2012).
} 
and Bayes-Stein as per equation (40). These foreign bias measures suggest that the top four investment destinations of Australian domiciled mutual funds are U.S., Japan, France and U.K.

I use Bayesian approach to allow for a degree of mistrust in the ICAPM. The Bayesian foreign bias measures are computed using squares of standard error of the estimates of intercepts reported in Table 3. I employ several levels of squares of standard errors of the estimates of intercepts (Table 3): country specific standard errors, minimum standard error ( $\left.\sigma_{\alpha}=0.25\right)$ for US, maximum standard error $\left(\sigma_{\alpha}=1.2\right)$ corresponding to Russia and intermediate standard error $\left(\sigma_{\alpha}=0.5\right)$. Columns (7), (9), (11) and (13) illustrate foreign bias measures for various levels of standard errors of intercepts: $\sigma_{\alpha}=$ country specific, $\sigma_{\alpha}=0.25$, $\sigma_{\alpha}=0.5$ and $\sigma_{\alpha}=1.2$. Bayesian estimates may lead to occasionally unstable portfolio weights and foreign bias measures. I apply Multi-Prior approach of Garlappi et al (2007) to account for volatility correction in weights estimated by Bayesian approach. Columns (8), (10), (12) and (14) illustrate foreign bias measures for various levels of standard errors: $\sigma_{\alpha}=$ country specific, $\sigma_{\alpha}=0.25, \sigma_{\alpha}=0.5$ and $\sigma_{\alpha}=1.2$. The Bayesian and Multi-Prior foreign bias measures suggest that Australian domiciled mutual funds prefer investing in developed economies like U.S., Japan, France, U.K., Germany, Switzerland, Canada, New Zealand and Netherlands. Australian domiciled mutual funds are found to under invest in emerging economies like Hungary, Pakistan, Poland, Chile and Czech Republic.

\section{[Table 5]}

Table 5 illustrates the average home bias measures (2002 to 2011) by using IMF's CPIS dataset on foreign equity holdings. The average foreign bias measures i.e. Minimum Variance (column (3)), Minimum Variance Multi-Prior (column (4), Bayes-Stein (column (5)) and Bayes-Stein Multi-Prior (column (6)) indicate that Australian domiciled mutual 
funds prefer investing in U.S., U.K., Switzerland, Netherlands and Japan. The Bayesian and Multi-Prior foreign bias measures suggest that Australian domiciled mutual funds prefer investing in developed economies like U.S., U.K., Japan, Netherlands, France, Germany, Switzerland, Hong Kong, Canada, Korea and New Zealand.

I would like to provide qualitative comparison of various methods employed to measure foreign bias. The traditional foreign bias measure is based on ICAPM approach and completely ignores returns. The mean variance approach uses data for the first and second sample moments and completely ignores the potential usefulness of an asset pricing model. The minimum variance frontier comprises of all portfolios that have minimum variance for a given level of expected return. The global minimum variance portfolios are suitable for investors who focus on low-risk stocks because the minimum variance portfolios exploit correlations only to the extent of achieving sole objective of lowering risk. In the case of Bayes Stein estimation, the mean-variance efficient portfolios are shrunk toward the minimum variance portfolio. The Bayes Stein approach imposes the prior assumption that all assets have the same expected return, irrespective of their risk profile. In Bayesian approach, the tangency portfolio is shrunk toward the market portfolio. The prior expected returns are inferred from CAPM and the shrinkage effect mainly depends on investor's degree of mistrust in the CAPM. I find slightly lower values of Bayesian foreign bias measures as compared to ICAPM foreign bias measures. Table 5 foreign equity measures computed using CPIS data have higher values as compared to foreign equity measures computed using Morningstar mutual fund database. The Bayesian foreign equity measures (Table 4 and Table 5) suggest that Australian domiciled mutual funds prefer investing in U.S., U.K., Japan, Netherlands, and other developed countries ${ }^{28}$. This is in accordance with Table 1 which illustrates that top destinations of Australian domiciled mutual funds holdings are U.S.,

\footnotetext{
${ }^{28}$ Mutual fund managers may adopt different strategies for managing portfolios i.e. buy and hold, market timing, performance weighting, momentum, quantitative and others.
} 
Japan, U.K., France and other developed countries. Section 6.2 explores plausible sources of home bias in Australian domiciled mutual fund holdings.

\section{Econometric Issues and Empirical Results}

\subsection{Econometric Issues}

To deal with basic problems of endogenity between variables the regression equation will be based on the Arellano-Bover/Blundell-Bond linear dynamic panel-data estimation. In these models, the unobserved panel level effects are correlated with the lagged dependent variables, making standard estimators inconsistent.

$$
y_{i t}=\delta y_{i, t-1}+x_{i t}^{\prime} \beta+u_{i t} \quad i=1, \ldots \ldots \ldots, N \quad t=2, \ldots \ldots \ldots \ldots . . T
$$

where $y_{i t}$ is home bias measure, $\delta$ is a scalar, $x_{i t}^{\prime}$ is a $1 \times K$ vector of explanatory variables and $\beta$ is a $K \times 1$ vector of parameters to be estimated. The error term $u_{i t}$ is composed of an unobserved effect and time-invariant effect $\mu_{i}$ and random disturbance term $v_{i t}$.

Building on the work of Arellano and Bover (1995), Blundell and Bond (1998) propose a system estimator that uses moment conditions in which lagged differences are used as instruments for the level equation in addition to the moment conditions of lagged levels as instruments for the differenced equation. This estimator is designed for datasets with many panels and few periods. The method assumes that there is no autocorrelation in the idiosyncratic errors and requires the initial condition that the panel-level effects be uncorrelated with the first difference of the first observation of the dependent variable.

\subsection{Empirical Results}

Tables 6 and 7 report results from estimating versions of equation $(41)^{29}$ by ArellanoBover/Blundell-Bond linear dynamic panel-data method with lags (1) and AR (2) tests over the period from 2002 to 2011 . Traditional home bias measure is the dependent variable.

\footnotetext{
${ }^{29}$ I also conduct fixed effects and random effects tests with clustered standard errors; and one-step GMM estimation. Results are available from author.
} 


\section{[Table 6]}

In Table 6, GDP per capita is positive and significant. This implies that Australian domiciled mutual funds prefer investing in high income level countries. Exchange rate volatility is negative and significant in all regressions implying that Australian domiciled mutual funds are found to invest significantly less in a country if real exchange rate volatility of that country is relatively high, in accordance with Mishra (2011). Turnover and stock market capitalization to GDP ratio variables are positive and significant, implying that Australian domiciled funds prefer investing in developed stock markets. More developed financial markets are generally more diversified and better integrated with world financial markets than smaller markets and hence likely to share information more intensively (Levine and Zervos, 1998). Language dummy is positive and significant which implies that Australian domiciled mutual funds prefer investing in common language countries. This is in accordance with Grinblatt and Keloharju's (2001) findings that investors are more likely to hold, buy and sell stocks of firms that communicate in the investors' native language. Distance is negative and significant. This is in accordance with Coval and Moskowitz (1999), who find that the weight of a US stock in US mutual funds is negatively related to the distance between the location of the fund and the location of the headquarters of the firm. Inflation variable appears to be negative and significant implying that Australian domiciled mutual funds do not prefer investing in countries with high inflation. Generally, high inflation rate means low level of economic stability. Legal dummy appears to be positive and significant implying that Australian domiciled funds prefer investing in countries which have common law system (U.S., U.K., Canada and others). Tax credit variable appears to be positive and significant in accordance with Mishra (2014). The availability of credits to Australian investors for tax already paid on dividends by foreign companies would attract equity investment abroad. 
Global financial crisis dummy is negative and significant. This implies that during GFC, Australian domiciled mutual funds decreased their holdings in foreign countries. Size variable appears to be negative and significant. This implies that Australian domiciled mutual funds make large domestic investments. Table 1 illustrates that Australian domiciled mutual funds have around $62 \%$ of their holdings within Australia as compared to Australia's weight of $2.20 \%$ in the world market capitalization. Annual return variable is positive and significant implying that Australian domiciled mutual funds prefer investing in stocks that yield high annual returns. Australian domiciled funds prefer stocks with higher price to book ratio, lower price to cash flow ratio, lower price to sales ratio and higher price to earnings ratio. Trade variable shows mixed results. Transaction cost variable is insignificant.

\section{[Table 7]}

In Table 7, foreign listing variable replaces GDPC. Foreign listing is positive and significant in all regressions. The reduction in information costs associated with foreign country's firms conforming to the source country's regulatory environment is an important determinant of the source country's equity bias towards foreign country. The result is in accordance with Ahearne et al. (2004). Other variables are similar to those in Table 6. The Arellano-Bond test for serial correlation in the first differenced errors reported in the Table 5 and Table 6 indicates that there is no autocorrelation of second order ${ }^{30}$.

Overall, results indicate that gross domestic product per capita, stock market capitalization to GDP ratio, turnover, familiarity variables, institution variables, other variables (tax credit, exchange rate volatility, foreign listing, and inflation), stock

\footnotetext{
${ }^{30}$ Results for various dependent home bias measures: Mean Variance, Bayes-Stein, Bayesian and Multi-prior home bias measures for 0.25 standard errors; Bayesian and Multi-prior home bias measures for 0.50 standard errors; Bayesian and Multi-prior home bias measures for 1.20 standard errors and data based approach are available from author.
} 
characteristics and global financial crisis have significant impact on Australian domiciled mutual fund holdings abroad ${ }^{31}$.

\section{Conclusion}

This paper constructs measures of Australian investors' foreign bias for a sample 41 countries by employing various approaches i.e. model based ICAPM; data based MeanVariance, Minimum-Variance; shrinkage based Bayes-Stein approach; Bayesian approach that reflects mistrust in ICAPM; and Multi-Prior approach which corrects uncertainty in sample estimates of returns and restricts the expected return for each asset to lie within a specified confidence interval of its estimated value. The Bayesian foreign equity measures (Table 6 and Table 7) suggest that Australian domiciled mutual funds prefer investing in U.S., U.K., Japan, Netherlands and other developed countries.

I also investigate plausible sources of foreign bias. Paper finds that gross domestic product per capita, stock market capitalization to GDP ratio, turnover, familiarity variables, institution variables, other variables (tax credit, exchange rate volatility, foreign listing, and inflation) and global financial crisis have significant impact on Australian domiciled mutual fund holdings abroad. Stock characteristics (annual returns, price book ratio, price cash flow ratio, price earnings ratio and price sales ratio) are found to significantly impact Australian domiciled mutual fund holdings abroad.

Findings have policy implications for Australia's foreign equity investment. Stock market regulation policies should aim at devising systems that promote foreign listing and enhance stock trading. Exchange rate volatility should be taken into account in formulating policies related to Australia's foreign equity investment. Cross border taxation policies should aim at increasing Australia's foreign equity investment.

\section{References}

\footnotetext{
${ }^{31}$ In Table 7, trade and correlation variables are insignificant.
} 
Ahearne, A.G., Griever, W.L., Warnock, F.E., 2004. Information costs and home bias: an analysis of US holdings of foreign equities. Journal of International Economics. 62, 313-336.

Arellano, M., Bover, O., 1995. Another look at the instrumental variable estimation of errorcomponents models. Journal of Econometrics. 68, 29-51.

Asgharian, H., Hansson, B., 2006. Home bias among European investors from a Bayesian perspective. Journal of International Financial Markets, Institutions and Money. 16, 397-410.

Baele, L., Pungulescu, C., Horst, J.T., 2007. Model uncertainty, financial market integration and the home bias puzzle. Journal of International Money and Finance. 26, 606-630.

Barron, J.M., Ni, J., 2008. Endogenous asymmetric information and international equity home bias: the effects of portfolio size and information costs. Journal of International Money and Finance. 27(4), 617-635.

Beakert, G., Wang, X., 2009. Home Bias Revisited. Available at SSRN: http://ssrn.com/abstract=1344880.

Best, M.J., Grauer, R.R., 1991. On the sensitivity of Mean-Variance-Efficient Portfolios to changes in asset means: some analytical and computational results. Review of Financial Studies. 4, 315-342.

Blundell, R., Bond, S., 1998. Initial conditions and moment restrictions in dynamic paneldata models. Journal of Econometrics. 87, 115-143.

Berger, J., 1974. Minimax estimator of a multivariate normal mean under polynomial loss. Journal of Multivariate Analysis. 8, 173-180.

Britten-Jones, M., 1994. The sampling error in estimates of mean-variance efficient portfolio weights. Journal of Finance. 54, 655-671.

Campbell, R.A., Kraussl, R., 2007. Revisiting the home bias puzzle: downside equity risk. Journal of International Money and Finance. 26, 1239-1260.

Chan, K., Covrig, V., Ng, L., 2005. What determines the domestic bias and foreign bias? evidence from mutual fund equity allocations worldwide. Journal of Finance. 60(3), 14951534.

Chopra, V.K., Ziemba, W.T., 1993. The effect of errors in means, variances, and covariances on optimal portfolio choice. Journal of Portfolio Management. 19, 6-11.

CIA (2012) World Factbook.

Coen, A., 2001. Home bias and international capital asset pricing model with human capital. Journal of Multinational Finance Management. 11, 497-513.

Coeurdacier, N., Rey, H., 2013. Home bias in open economy financial macroeconomics. Journal of Economic Literature. 51(1), 63-115. 
Coval, J., Moskowitz, T., 1999. Home Bias at home: local equity preference in domestic portfolios. Journal of Finance. 54, 2045-2073.

Dahlquist, M., Pinkowitz, L., Stulz, R., Williamson, R., 2003. Corporate governance and home bias. Journal of Financial and Quantitative Analysis. 38(1), 135-157.

Dahlquist, M., Robertsson, G., 2003. Direct foreign ownership, institutional investors, and firm characterstics. Journal of Financial Economics. 59, 413-440.

Demirgfii-Kunt, A., Levine, R., 1996. Stock Market Development and Financial Intermediaries: Stylized Facts. World Bank Economic Review. 19(2), 291 - 322.

French, K., Poterba, J., 1991. Investor diversification and international equity markets, American Economic Review, Papers and Proceedings of the Hundred and Third Annual Meeting of the American Economic Association. 2, 222-226.

Garlappi, L., Uppal, R., Wang, T., 2007. Portfolio selection with parameter and model uncertainty: a multi-prior approach. Review of Financial Studies. 20, 41-81.

Glassman, D.A., Riddick, L.A., 2001. What causes home asset bias and how should it be measured? Journal of Empirical Finance. 8, 35-54.

Gompers, P.A., Metrick, A., 2001. Institutional investors and equity prices. Quarterly Journal of Economics. 116, 229-259.

Gorman, L.R., Jorgensen, B.N., 2002. Local versus international portfolio selection: a statistical examination of home bias. Multinational Finance Journal. 6, 131-166.

Grinblatt, M., Keloharju, M., 2001. How distance, language and culture influence stockholdings and trades. Journal of Finance. 56, 1053-1073.

Hasan, I., Simaan, Y., 2000. A Rational Explanation for home country bias. Journal of International Money and Finance. 19, 331-361.

Herold, H., Maurer, R., 2003. Bayesian Asset Allocation and U.S. Domestic Bias. Financial Analysts Journal. 59 (6), 54-65.

Hodges, S.D., Brealey, R.A., 1978. Portfolio selection in a dynamic and uncertain world, in J.H. Lorie and R.A. Brealey (eds.), Modern Developments in Investment Management (2d ed.), Dryden Press, Hinsdale, Illionois.

Huberman, G., 2001. Familiarity Breeds Investment. Review of Financial Studies. 14 (3), 659-680.

Jeske, K., 2001. Equity home bias: can information cost explain the puzzle? Economic Review, Federal Reserve Bank of Atlanta. Q3, 31-42.

Jorion, P., 1985. International portfolio diversification with estimation risk. The Journal of Business. 58(3), 259-278. 
Jorion, P., 1986. Bayes-Stein estimation for portfolio analysis. The Journal of Financial and Quantitative Analysis. 21(3), 279-292.

Kho, B.C., Stulz, R.M., Warnock, F.E., 2009. Financial Globalization, Governance and the Evolution of the Home Bias. Journal of Accounting Research. 47(2), 637-646.

Knight, F., 1921. Risk, uncertainty and Profit. Houghton Mifflin, Boston.

Koop, G., 2003. Bayesian Econometrics. John Wiley \& Sons Ltd., England.

Lane, P.R., Milesi-Ferretti, G.M., 2008. International investment patterns. The Review of Economics and Statistics. 90(3), 538-549.

La Porta, F.L., Lopez-de-Silanes, F., Shleifer, A., Vishney, R.W., 1998. Law and Finance. Journal of Political Economy. 106 (6), 1113-1155.

La Porta, F.L., Lopez-de-Silanes, F., Shleifer, A., Vishney, R.W., 1997. Legal determinants of external finance. Journal of Finance. 52 (3), 1131-1150.

Ledoit, O., Wolf, M., 2003. Improved estimation of the covariance matrix of stock returns with an application to portfolio selection. Journal of Empirical Finance. 10(5), 603-621.

Levine, R., Zervos, S. (1998). Stock markets, banks and economic growth. The American Economic Review. 88(3), 537-558.

Li, K., 2004. Confidence in the familiar: an international perspective. Journal of Financial and Quantitative Analysis. 39, 47-68.

Lintner, J., 1965. The valuation of risky assets and the selection of risky investment in stock portfolio and capital budgets. Review of Economics and Statistics. 47, 103-124.

Litterman, R., 2003. Modern Investment Management: An Equilibrium Approach, Wiley, New York.

Lutje, T., Menkhoff, L., 2007. What drives home bias? Evidence from fund managers' views. International Journal of Finance and Economics. 12(1), 21-35.

Markowitz, H.M., 1952. Mean-Variance analysis in portfolio choice and capital markets. Journal of Finance. 7, 77-91.

Merton, R., 1973. An analytic derivation of the efficient portfolio frontier. Journal of Financial and Quantitative Analysis. 7, 1851-1872.

Merton, R., 1980. On estimating the expected return on the market: an exploratory investigation. Journal of Financial Economics. 8, 323-361.

Michaud, R.O., 1989. The Markowitz optimization enigma: is optimized optimal? Financial Analysts Journal. 45, 31-42. 
Mishra, A.V., 2011. Australia's equity home bias and real exchange rate volatility. Review of Quantitative Finance and Accounting. 37(2), 223-244.

Mishra, A.V., 2014. Australia's home bias and cross border taxation. Global Finance Journal. $25,108-123$.

Mondria, J., Wu, T., 2010. The puzzling evolution of the home bias, information processing and financial openness. Journal of Economic Dynamics and Control. 34, 875-896.

Moor, L.D., Sercu, P., Vanpee, R., 2010. The plausibility of risk estimates and implied costs to international equity investments. Journal of Empirical Finance 17, 623-644.

Nieuwerburgh, S.V., Veldkamp, L., 2009. Information immobility and home bias puzzle. Journal of Finance. 64(3), 1187-1215

Pastor, L., 2000. Portfolio selection and asset pricing models. Journal of Finance. 55, 179223.

Pastor, L., Stambaugh, R.F., 2000. Comparing asset pricing models: an investment perspective. Journal of Financial Economics. 56, 335-381.

Pesenti, P., Van Wincoop, E., 2002. Can nontradables generate substantial home bias? Journal of Money, Credit and Banking. 34, 26-50.

Sarkissian, S., Schill, M.J., 2004. The overseas listing decision: new evidence of proximity preference. The Review of Financial Studies. 17 (3), 769-809.

Sercu, Piet, Vanpée, R. (2012). The Home Bias Puzzle in Equity Portfolios. In H. K. Baker \& L. A. Riddick (Eds.), Survey of International Finance. Oxford University Press.

Sharpe, W., 1964. Capital asset prices: A theory of market equilibrium under the condition of risk. Journal of Finance. 19, 425-442.

Solnik, B., Zuo, L., 2012. A global equilibrium asset pricing model with home preference. Management Science. 58(2), 273-292.

Standard and Poor's, 2012. Standard and Poor's Stock Market Factbook, NY.

Stein, C., 1955. Inadmissibility of the usual estimator for the mean of a multivariate normal distribution, in $3^{\text {rd }}$ Berkely Symposium on Probability and Statistics, vol. 1, pp. 197-206, University of California Press, Berkeley.

Strong, N.C., Xu, X., 2003. Understanding the equity home bias: evidence from survey data. Review of Economics and Statistics. 85, 307-312.

Suh, J., 2005. Home bias among institutional investors: a study of the Economist Quarterly Portfolio Poll. Journal of the Japanese and International Economies. 19, 72-95.

Tesar, L., Werner, I.M., 1995. Home bias and high turnover. Journal of International Money and Finance. 14, 467-493. 
Wang, Z., 2005. A shrinkage approach to model uncertainty and asset allocation. Review of Financial Studies. 18, 673-705.

Warren, G.J., 2010. Equity home bias in Australian superannuation funds. Australian Journal of Management. 35(1), 69-93.

World Development Indicators, 2012. World Bank, Washington D.C.

Zellner, A., 2010. Bayesian shrinkage estimates and forecasts of individual and total or aggregate outcomes. Economic Modelling. 27, 1392-1397.

Zellner, A., Chetty, V.K., 1965. Prediction and decision problems in regression models from the Bayesian point of view. Journal of American Statistical Association. 60, 608-615. 
Appendix Table A.1: Data sources of variables

Variables
Traditional foreign bias
Mean Variance foreign bias
Minimum Variance foreign bias
Bayes-Stein foreign bias
Bayesian (country standard
error) foreign bias
Bayesian (0.25 standard error)
foreign bias

Description and data sources

Traditional foreign bias is absolute home bias measure computed as per the ICAPM model. Source: Morningstar, Coordinated Portfolio Investment Survey (CPIS), Author's own calculations.

Mean-Variance foreign bias computed based on the Mean-Variance approach. Source: Morningstar, CPIS, Author's own calculations.

Minimum Variance home bias computed as per the Minimum-Variance framework. Source: Morningstar, CPIS, Author's own calculations.

Bayes-Stein foreign bias computed as per the Bayes-Stein model. Source: Morningstar, CPIS, Author's own calculations.

Bayesian (country standard error) foreign bias computed in Bayesian framework for prior country specific standard errors of alpha intercept in the ICAPM. Source: Morningstar, CPIS, Author's own calculations.

foreign bias

Bayesian (0.25 standard error) foreign bias computed in Bayesian framework for prior 0.25 standard errors of alpha intercept in the ICAPM. Source: Morningstar, CPIS, Author's own calculations.

Bayesian (0.5 standard error) Bayesian (0.5 standard error) home bias computed in Bayesian framework foreign bias for prior 0.5 standard errors of alpha intercept in the ICAPM. Source: Morningstar, CPIS, Author's own calculations.

Bayesian (1.2 standard error) Bayesian (1.2 standard error) home bias computed in Bayesian framework foreign bias for prior 1.2 standard errors of alpha intercept in the ICAPM. Source: Morningstar, CPIS, Author's own calculations.

Multi-Prior (data based) foreign Multi-Prior (data based) is multi prior correction as suggested by Garlappi et bias al (2007) for data based approach. Source: Morningstar, CPIS, Author's own calculations.

Multi-Prior (Bayes-Stein) Multi-Prior (Bayes-Stein) is multi prior correction as suggested by Garlappi foreign bias et al (2007) for Bayes-Stein approach. Source: Morningstar, CPIS, Author's own calculations.

Multi-Prior (country standard Multi-Prior (country standard error) is multi prior correction as suggested by error) foreign bias Garlappi et al (2007) in Bayesian framework for prior country specific standard errors of alpha intercept in the ICAPM. Source: Morningstar, CPIS, Author's own calculations.

Multi-Prior (0.25 standard error) Multi-Prior (0.25 standard error) is multi prior correction as suggested by foreign bias Garlappi et al (2007) in Bayesian framework for prior 0.25 standard errors of alpha intercept in the ICAPM. Source: Morningstar, CPIS, Author's own calculations.

Multi-Prior (0.5 standard error) Multi-Prior (0.5 standard error) is multi prior correction as suggested by foreign bias Garlappi et al (2007) in Bayesian framework for prior 0.5 standard errors of alpha intercept in the ICAPM. Source: Morningstar, CPIS, Author's own calculations.

Multi-Prior (1.2 standard error) Multi-Prior (1.2 standard error) is multi prior correction as suggested by foreign bias Garlappi et al (2007) in Bayesian framework for prior 1.2 standard errors of alpha intercept in the ICAPM. Source: Morningstar, CPIS, Author's own calculations.

GDP per capita GDP per capita is log value of ratio of gross domestic product to mid-year population. Source: World Bank World Development Indicators., Author's own calculations.

Trade Trade is $\log$ value of ratio of sum of exports and imports of goods and services to gross domestic product. Source: World Bank Development Indicators, Author's own calculations. 
Stock market capitalisation GDP

Turnover

Size
Stock market capitalisation to GDP is log value of ratio of stock market capitalisation to gross domestic product. Source: World Bank Development Indicators, Author's own calculations.

Turnover is the log value of ratio of total value of shares traded during the period to market capitalization during the period. Source: DataStream. Author's own calculations.

Size is country's market share of world market capitalization. Source:

Standard \& Poor's Global Stock Markets Factbook, Author's own calculations.

\begin{tabular}{|c|c|}
\hline Variables & Description and data sources \\
\hline Transaction cost & $\begin{array}{l}\text { Transaction cost is } \log \text { value of foreign country's transaction cost. Source: } \\
\text { Elkins-McSherry Co. (www.elkinsmcsherry.com). }\end{array}$ \\
\hline Language & $\begin{array}{l}\text { Language is dummy }=1 \text { if foreign country's language is English otherwise } 0 . \\
\text { Source: CIA World Factbook. }\end{array}$ \\
\hline \multirow[t]{2}{*}{ Distance } & $\begin{array}{l}\text { Distance is logarithm of distance between capital city of Australia and } \\
\text { capital city of foreign country. }\end{array}$ \\
\hline & Source:http://www.timeanddate.com/worldclock/distance.html. \\
\hline Quality & $\begin{array}{l}\text { Quality is log value of average of World Bank governance indicators i.e. } \\
\text { rule of law, control of corruption, regulatory quality and government } \\
\text { effectiveness. Source: www.govindicators.org. }\end{array}$ \\
\hline Legal & $\begin{array}{l}\text { Legal is dummy=1 if foreign country has common law system otherwise } 0 . \\
\text { Source: CIA-The World Factbook. }\end{array}$ \\
\hline Correlation & $\begin{array}{l}\text { Correlation is correlation of monthly returns of Australia and foreign } \\
\text { country over the years } 1995 \text { to } 2011 \text {. Source: MSCI market indices. }\end{array}$ \\
\hline Tax credit & $\begin{array}{l}\text { Tax credit is product of foreign dividend tax withheld rate and dividend } \\
\text { yield if foreign dividend tax withheld rate is less than or equal to home } \\
\text { country's combined corporate income tax rate. It is product of home } \\
\text { country's combined corporate income tax rate and foreign dividend yield if } \\
\text { foreign dividend tax withheld rate is greater than home country's combined } \\
\text { corporate income tax. Source: Price Waterhouse, 2002-2012. }\end{array}$ \\
\hline Exchange rate volatility & $\begin{array}{l}\text { Exchange rate volatility is logarithm of standard deviation of monthly real } \\
\text { exchange rate changes over the period } 1995 \text { to } 2011 \text {. Source: DataStream. } \\
\text { Author's own calculations. }\end{array}$ \\
\hline Foreign listing & $\begin{array}{l}\text { Foreign listing is logarithm of share of global stock market that is listed on } \\
\text { source country's stock exchanges (either directly or has issued public debt in } \\
\text { the source country). Source: CPIS. Author's own calculations. }\end{array}$ \\
\hline Inflation & $\begin{array}{l}\text { Inflation is annual percentage change in consumer price index. Source: } \\
\text { World Bank World Development Indicators. }\end{array}$ \\
\hline Annual return & $\begin{array}{l}\text { Annual return is logarithm of annualized return of fund. It represents } \\
\text { shareholders' gains during the stated calendar year. Source: Morningstar } \\
\text { (www.morningstar.com.au). }\end{array}$ \\
\hline Price Book ratio & $\begin{array}{l}\text { Price book ratio of a company is calculated by dividing the market price of } \\
\text { its stock by the company's per-share book value. Price book ratio is } \\
\text { weighted average of the price/book ratios of all the stocks in a portfolio. } \\
\text { Source: Morningstar (www.morningstar.com.au). }\end{array}$ \\
\hline Price Cash flow ratio & $\begin{array}{l}\text { Price cash flow ratio is a stock's most recent price divided by its cash-flow } \\
\text { per share during the most recent fiscal year. Price Cash flow ratio is the } \\
\text { weighted average of the price/cash-flow ratios of the stocks in a portfolio. } \\
\text { Source: Morningstar (www.morningstar.com.au). }\end{array}$ \\
\hline Price Earnings ratio & $\begin{array}{l}\text { Price Earnings ratio of a stock is calculated by dividing the current price of } \\
\text { the stock by its trailing } 12 \text { months' earnings per share. Price Earnings ratio } \\
\text { is weighted average of the price/earnings ratios of the stocks in a portfolio. } \\
\text { Source: Morningstar (www.morningstar.com.au). }\end{array}$ \\
\hline Price Sales ratio & $\begin{array}{l}\text { Price/sales is a stock's current price divided by its sales per share over the } \\
\text { trailing } 12 \text { months. Price Sales ratio represents the weighted average of the } \\
\text { price/sales ratios of the stocks in a portfolio. Source: Morningstar } \\
\text { (www.morningstar.com.au). }\end{array}$ \\
\hline Global Financial crisis & $\begin{array}{l}\text { Dummy }=1 \text { during global financial crisis (2008) otherwise } 0 \text { (2001 to 2007; } \\
2009 \text { to 2011). Source: Author's own calculations. }\end{array}$ \\
\hline
\end{tabular}


Table 1: Australian domiciled mutual funds equity allocations

\begin{tabular}{|c|c|c|c|}
\hline Countries & $\begin{array}{l}\text { Average Mutual Fund } \\
\text { Holdings } \\
\text { (US \$ million) }\end{array}$ & $\begin{array}{l}\text { Average } \\
\text { Allocation } \\
\text { (Percent) }\end{array}$ & $\begin{array}{l}\text { Average Market Capital } \\
\text { Weight (Percent) }\end{array}$ \\
\hline Australia & 67654 & 62.78 & 2.20 \\
\hline US & 28501.21 & 13.79 & 38.36 \\
\hline Japan & 17478.92 & 6.85 & 8.92 \\
\hline UK & 8446.15 & 3.85 & 6.47 \\
\hline France & 5114.26 & 2.28 & 4.20 \\
\hline Germany & 4494.51 & 2.08 & 3.07 \\
\hline Canada & 2515.35 & 1.21 & 3.39 \\
\hline Switzerland & 2539.05 & 1.17 & 2.29 \\
\hline New Zealand & 1109.24 & 0.96 & 0.10 \\
\hline Netherlands & 1428.04 & 0.64 & 1.42 \\
\hline China & 1114.91 & 0.55 & 5.84 \\
\hline Hong Kong & 1186.76 & 0.54 & 2.38 \\
\hline Korea & 831.39 & 0.43 & 1.60 \\
\hline Italy & 583.93 & 0.31 & 1.56 \\
\hline Spain & 488.61 & 0.27 & 2.48 \\
\hline Brazil & 509.93 & 0.25 & 1.69 \\
\hline Singapore & 528.79 & 0.25 & 0.70 \\
\hline Finland & 478.30 & 0.20 & 0.45 \\
\hline Taiwan & 382.90 & 0.20 & 1.28 \\
\hline Sweden & 359.07 & 0.18 & 0.96 \\
\hline South Africa & 333.51 & 0.18 & 1.38 \\
\hline India & 317.63 & 0.16 & 1.82 \\
\hline Belgium & 346.92 & 0.16 & 0.60 \\
\hline Norway & 350.89 & 0.15 & 0.44 \\
\hline Thailand & 297.44 & 0.15 & 0.35 \\
\hline Denmark & 164.26 & 0.08 & 0.41 \\
\hline Austria & 112.21 & 0.06 & 0.22 \\
\hline Mexico & 99.61 & 0.05 & 0.64 \\
\hline Russia & 95.95 & 0.05 & 1.45 \\
\hline Israel & 98.64 & 0.05 & 0.32 \\
\hline Malaysia & 64.00 & 0.03 & 0.58 \\
\hline Greece & 39.00 & 0.02 & 0.28 \\
\hline Indonesia & 43.48 & 0.02 & 0.35 \\
\hline Turkey & 32.55 & 0.02 & 0.37 \\
\hline Portugal & 28.14 & 0.01 & 0.19 \\
\hline Philippines & 23.96 & 0.01 & 0.18 \\
\hline Argentina & 20.21 & 0.01 & 0.16 \\
\hline Hungary & 12.17 & 0.01 & 0.06 \\
\hline Chile & 7.52 & 0.00 & 0.39 \\
\hline Poland & 7.90 & 0.00 & 0.25 \\
\hline Czech Republic & 5.89 & 0.00 & 0.10 \\
\hline Pakistan & 0.25 & 0.00 & 0.08 \\
\hline
\end{tabular}

Note: Table illustrates equity allocations of Australian domiciled mutual funds equity allocations in Australia and 41 foreign countries. Column (1) illustrates average mutual fund equity allocations in US \$ million. Column (2) illustrates average percentage ratio of Australian domiciled mutual fund equity allocations to total allocation of Australian domiciled mutual fund equity in Australia and across 41 countries. Column (3) illustrates average percent world market capitalization weight of each country. 
Table 2: Summary Statistics

\begin{tabular}{|c|c|c|c|c|c|c|c|c|c|c|c|c|c|c|c|c|c|c|c|c|}
\hline \multicolumn{3}{|c|}{ Economic Development } & \multicolumn{4}{|c|}{ Stock Market Development } & \multicolumn{2}{|c|}{ Familiarity } & \multicolumn{2}{|c|}{ Institution } & \multicolumn{5}{|c|}{ Other Variables } & \multicolumn{5}{|c|}{ Stock Characteristics } \\
\hline Country & GDPPC & TR & SMCAP & TURN & SIZ & TRAN & LAN & DIS & QUA & LEG & COR & TX & VL & FL & INFL & $\mathrm{AR}$ & PB & $\mathrm{PC}$ & $\mathrm{PE}$ & PS \\
\hline US & 10.65 & -1.36 & 0.14 & 0.63 & 39.53 & -1.65 & 1 & 4.20 & 0.44 & 1 & 0.70 & 0.24 & -3.61 & -1.80 & 2.59 & -2.12 & 0.94 & 2.25 & 2.76 & 0.44 \\
\hline UK & 10.49 & -0.55 & 0.20 & 0.28 & 6.71 & -0.75 & 1 & 4.22 & 0.54 & 0 & 0.69 & 0 & -3.19 & -2.63 & 2.17 & -2.14 & 0.92 & 2.21 & 2.73 & 0.41 \\
\hline JAP & 10.49 & -1.32 & -0.27 & 0.08 & 8.92 & -1.70 & 0 & 3.89 & 0.20 & 0 & 0.61 & 0.18 & -3.17 & -2.84 & 0.34 & -2.59 & 0.81 & 2.10 & 2.78 & 0.33 \\
\hline FRA & 10.43 & -0.63 & -0.27 & -0.02 & 4.20 & -1.42 & 0 & 4.22 & 0.33 & 0 & 0.65 & 0.71 & -3.49 & -3.96 & 1.83 & -2.57 & 0.80 & 2.11 & 2.77 & 0.33 \\
\hline GER & 10.44 & -0.24 & -0.86 & 0.32 & 3.06 & -1.45 & 0 & 4.20 & 0.49 & 0 & 0.65 & 0.35 & -3.49 & -4.29 & 1.56 & -2.57 & 0.82 & 2.10 & 2.78 & 0.32 \\
\hline CAN & 10.47 & -0.38 & 0.08 & -0.30 & 3.39 & -1.33 & 1 & 4.19 & 0.59 & 1 & 0.74 & 0.33 & -3.66 & -4.45 & 2.17 & -2.36 & 0.84 & 2.10 & 2.71 & 0.36 \\
\hline SWI & 10.91 & -0.12 & 0.77 & 0.02 & 2.29 & -1.42 & 0 & 4.21 & 0.63 & 0 & 0.57 & 0.27 & -3.27 & -4.57 & 0.72 & -2.57 & 0.85 & 2.10 & 2.78 & 0.26 \\
\hline NZ & 10.16 & -0.50 & -0.98 & -0.89 & 0.10 & -1.17 & 1 & 3.36 & 0.66 & 1 & 0.72 & 0.79 & -3.87 & -5.01 & 2.52 & -1.71 & 1.03 & 2.31 & 2.71 & 0.44 \\
\hline NET & 10.59 & -0.59 & -1.35 & -1.33 & 1.41 & -1.44 & 0 & 4.22 & 0.62 & 0 & 0.64 & 0.51 & -3.49 & -4.21 & 4.35 & -2.51 & 0.84 & 2.07 & 2.79 & 0.29 \\
\hline CHI & 7.78 & -0.52 & -0.51 & 0.21 & 5.84 & -0.85 & 0 & 3.95 & NA & 0 & 0.53 & 0.34 & -3.45 & NA & 2.56 & -2.60 & NA & NA & NA & NA \\
\hline HK & 10.23 & 1.30 & 1.39 & -0.36 & 2.38 & -0.96 & 0 & 3.86 & 0.56 & 1 & 0.58 & 0 & -3.45 & -3.23 & 1.43 & -2.35 & 0.84 & 2.17 & 2.75 & 0.39 \\
\hline KOR & 9.73 & -0.26 & -0.40 & 0.74 & 1.53 & -0.68 & 0 & 3.92 & -0.21 & 0 & 0.62 & 0.24 & -2.89 & -6.63 & 3.08 & -2.66 & 0.82 & 2.14 & 2.73 & 0.25 \\
\hline ITA & 10.32 & -0.60 & -1.08 & 0.29 & 1.56 & -1.29 & 0 & 4.20 & -0.65 & 0 & 0.56 & 0.57 & -3.49 & -5.50 & 2.03 & -2.64 & 0.81 & 2.02 & 2.76 & 0.24 \\
\hline SPA & 10.16 & -0.56 & -0.17 & 0.46 & 2.44 & -1.27 & 0 & 4.24 & 0.19 & 0 & 0.65 & 0.51 & -3.50 & -5.75 & 3.05 & -2.69 & 0.84 & 2.03 & 2.76 & 0.14 \\
\hline BRA & 8.61 & -1.35 & -0.67 & -0.76 & 1.68 & -0.92 & 0 & 4.14 & -3.23 & 0 & 0.63 & 0 & -2.65 & -12.58 & 6.13 & -2.66 & 0.85 & 2.14 & 2.77 & 0.32 \\
\hline SIN & 10.31 & 1.37 & 0.53 & -0.49 & 0.67 & -1.05 & 1 & 3.79 & 0.67 & 1 & 0.64 & 0 & -3.63 & -3.79 & 1.11 & -2.62 & 0.81 & 2.14 & 2.70 & 0.38 \\
\hline FIN & 10.55 & -0.24 & -0.17 & 0.18 & 0.44 & -1.16 & 0 & 4.18 & 0.72 & 0 & 0.49 & 0.76 & -3.46 & -6.93 & 1.38 & -2.78 & 0.78 & 1.93 & 2.74 & 0.20 \\
\hline TAI & N.A. & N.A. & N.A. & N.A. & 1.27 & -0.75 & 0 & 3.86 & -0.03 & 0 & 0.51 & 0.45 & -3.55 & NA & 1.03 & -2.54 & 0.84 & 2.13 & 2.73 & 0.25 \\
\hline SWE & 10.63 & -0.11 & -0.01 & 0.17 & 0.95 & -1.39 & 0 & 4.19 & 0.65 & 0 & 0.64 & 0.39 & -3.52 & -5.38 & 1.64 & -2.73 & 0.82 & 2.07 & 2.81 & 0.37 \\
\hline SA & 8.50 & -0.52 & 0.69 & -0.69 & 1.32 & -0.89 & 0 & 4.03 & -0.98 & 0 & 0.73 & 0 & -3.06 & -9.08 & 5.30 & -2.56 & 0.86 & 2.16 & 2.69 & 0.24 \\
\hline IND & 6.71 & -0.89 & -0.48 & 0.01 & 1.81 & -0.62 & 0 & 4.01 & NA & 1 & 0.45 & 0.19 & -3.51 & -12.47 & 6.26 & -2.29 & 0.87 & 2.16 & 2.77 & 0.28 \\
\hline BEL & 10.51 & 0.42 & -0.50 & -0.88 & 0.60 & -1.39 & 0 & 4.22 & 0.36 & 0 & 0.52 & 0.60 & -3.49 & -5.72 & 1.95 & -2.64 & 0.84 & 2.01 & 2.74 & 0.05 \\
\hline NOR & 11.12 & -0.34 & -0.65 & 0.07 & 0.43 & -1.30 & 0 & 4.20 & 0.59 & 0 & 0.72 & 0.58 & -3.48 & -5.01 & 1.84 & -2.54 & 0.90 & 2.19 & 2.80 & 0.28 \\
\hline THA & 8.01 & 0.31 & -0.45 & -0.10 & 0.33 & -0.71 & 0 & 3.87 & -2.26 & 0 & 0.64 & 0.29 & -3.22 & -7.01 & 2.78 & -3.16 & 0.68 & 2.04 & 2.57 & 0.08 \\
\hline DEN & 10.78 & -0.06 & -0.49 & -0.23 & 0.09 & -1.31 & 0 & 4.20 & 0.74 & 0 & 0.56 & 0.32 & -3.40 & -6.83 & 1.99 & -2.88 & 0.89 & 2.02 & 2.78 & 0.05 \\
\hline AUST & 10.56 & -0.90 & 0.13 & -0.16 & 0.22 & -1.34 & 0 & 4.20 & 0.58 & 0 & 0.53 & 0.30 & -3.49 & -6.20 & 2.81 & -2.46 & 0.87 & 2.13 & 2.77 & 0.32 \\
\hline MEX & 9.01 & -0.59 & -1.33 & -1.31 & 0.64 & -1.13 & 0 & 4.11 & -3.63 & 0 & 0.64 & 0.30 & -3.23 & -11.93 & 4.35 & -2.82 & 0.92 & 2.21 & 2.79 & 0.33 \\
\hline RUS & 8.70 & -0.60 & -0.56 & -0.51 & 1.39 & -1.16 & 0 & 4.16 & NA & 0 & 0.41 & 0.27 & -3.18 & -7.43 & 11.70 & -2.89 & 0.86 & 2.15 & 2.78 & 0.24 \\
\hline ISR & 10.01 & -0.26 & -0.25 & -0.47 & 0.32 & -1.11 & 0 & 4.14 & 0.01 & 0 & 0.47 & 0.91 & -3.34 & -8.18 & 2.40 & -3.01 & 0.86 & 2.18 & 2.78 & 0.26 \\
\hline MAL & 8.72 & 0.63 & 0.29 & -1.14 & 0.58 & -0.80 & 0 & 3.81 & -0.54 & 0 & 0.29 & 0 & -3.09 & -8.23 & 1.92 & -2.44 & 0.83 & 2.13 & 2.79 & 0.38 \\
\hline GRE & 10.01 & -0.57 & -0.94 & -0.76 & 0.27 & -0.74 & 0 & 4.18 & -0.51 & 0 & 0.43 & 0.74 & -3.50 & -9.45 & 3.43 & -2.39 & 0.94 & 2.14 & 2.79 & 0.22 \\
\hline INDO & 7.37 & -0.58 & -1.21 & -0.69 & 0.35 & -0.48 & 0 & 3.73 & NA & 0 & 0.39 & 0.39 & -3.08 & -9.58 & 6.50 & -2.37 & 0.88 & 2.16 & 2.77 & 0.32 \\
\hline TUR & 8.86 & -0.70 & -1.32 & 0.44 & 0.35 & -0.78 & 0 & 4.16 & -0.95 & 0 & 0.50 & 0.26 & -3.03 & -15.24 & 10.02 & -2.62 & 0.85 & 2.14 & 2.74 & 0.19 \\
\hline POR & 9.83 & -0.39 & -0.99 & -0.53 & 0.18 & -1.32 & 0 & 4.25 & 0.03 & 0 & 0.49 & 0.64 & -3.50 & -7.58 & 2.70 & -2.49 & 0.92 & 2.18 & 2.79 & 0.22 \\
\hline PHIL & 7.27 & -0.13 & -0.78 & -1.78 & 0.17 & -0.24 & 1 & 3.79 & NA & 0 & 0.53 & 0.32 & -3.31 & -9.23 & 4.53 & -2.25 & 0.86 & 2.21 & 2.69 & 0.42 \\
\hline ARG & 8.65 & -1.05 & -1.53 & -2.60 & 0.16 & -0.50 & 0 & 4.07 & NA & 0 & 0.45 & 0.42 & -2.65 & -11.68 & 9.55 & -2.73 & 0.83 & 1.98 & 2.77 & 0.16 \\
\hline HUN & 9.30 & 0.38 & -1.48 & -0.26 & 0.06 & -0.81 & 0 & 4.19 & -0.19 & 0 & 0.56 & 0.38 & -3.43 & -11.11 & 4.76 & -2.49 & 0.82 & 2.12 & 2.72 & 0.15 \\
\hline CHIL & 9.05 & -0.35 & 0.07 & -1.87 & 0.39 & -0.60 & 0 & 4.05 & 0.29 & 0 & 0.60 & 0.82 & -3.38 & -9.80 & 2.37 & -2.18 & NA & NA & NA & NA \\
\hline POL & 9.08 & -0.13 & -0.77 & -1.74 & 0.24 & -1.03 & 0 & 4.19 & -0.25 & 0 & 0.62 & 0.35 & -3.44 & -11.85 & 4.32 & -3.17 & NA & NA & NA & NA \\
\hline CZE & 9.52 & 0.23 & -1.38 & -0.51 & 0.10 & -0.76 & 0 & 4.20 & -0.17 & 0 & 0.42 & 0.75 & -3.36 & -9.43 & 1.89 & -3.36 & 0.69 & 2.03 & 2.66 & 0.11 \\
\hline PAK & 6.66 & -1.10 & -1.45 & 0.46 & 0.07 & N.A. & 0 & 4.04 & NA & 0 & 0.16 & 0.49 & -3.41 & -15.23 & 9.79 & -2.16 & NA & NA & NA & NA \\
\hline
\end{tabular}

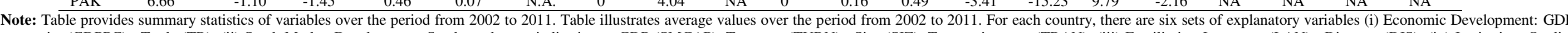

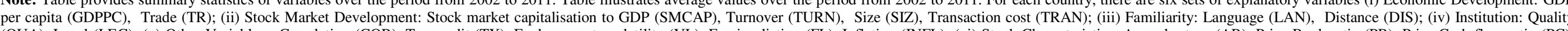

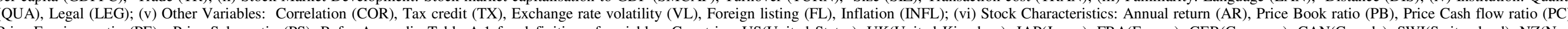

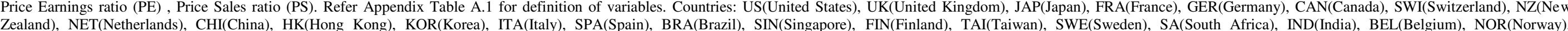

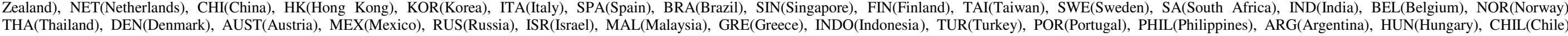
POL(Poland), CZE(Czech Republic), PAK(Pakistan). N.A. is not available. 
Table 3: ICAPM tests

\begin{tabular}{|c|c|c|c|c|c|}
\hline Country & Alpha & $\begin{array}{l}\text { Standard Error } \\
\text { of Alpha }\end{array}$ & Beta & $\begin{array}{l}\text { Standard Error } \\
\text { of Beta }\end{array}$ & $\mathrm{R}^{2}(\%)$ \\
\hline Argentina & 0.180 & 0.902 & 0.261 & 0.430 & 1 \\
\hline Austria & -0.115 & 0.383 & 0.480 & 0.182 & 12 \\
\hline Belgium & 0.360 & 0.277 & $0.477 * * *$ & 0.132 & 21 \\
\hline Brazil & -0.451 & 1.073 & 0.315 & 0.512 & 1 \\
\hline Canada & 0.264 & 0.303 & $0.468 * * *$ & 0.144 & 17 \\
\hline Chile & -0.034 & 0.603 & 0.136 & 0.287 & 1 \\
\hline China & -0.562 & 0.530 & $0.585 * *$ & 0.253 & 10 \\
\hline Czech Republic & -0.387 & 0.398 & 0.013 & 0.190 & 1 \\
\hline Denmark & 0.309 & 0.286 & $0.390 * * *$ & 0.136 & 14 \\
\hline Finland & 0.020 & 0.586 & $0.534^{*}$ & 0.279 & 7 \\
\hline France & 0.216 & 0.364 & $0.353 * *$ & 0.173 & 8 \\
\hline Germany & 0.290 & 0.257 & $0.375^{* * *}$ & 0.123 & 16 \\
\hline Greece & 0.159 & 0.519 & $0.582 * *$ & 0.247 & 10 \\
\hline Hong Kong & 0.257 & 0.457 & 0.491 & 0.218 & 9 \\
\hline Hungary & -0.427 & 0.487 & $0.444^{*}$ & 0.232 & 7 \\
\hline India & -0.741 & 0.473 & $0.389 *$ & 0.226 & 6 \\
\hline Indonesia & 0.105 & 0.472 & $0.504 * *$ & 0.225 & 9 \\
\hline Israel & 0.384 & 0.496 & 0.359 & 0.236 & 4 \\
\hline Italy & -0.036 & 0.501 & $0.706 * * *$ & 0.239 & 15 \\
\hline Japan & -0.032 & 0.422 & $0.690 * * *$ & 0.201 & 19 \\
\hline Korea & -0.081 & 0.463 & 0.346 & 0.220 & 5 \\
\hline Malaysia & 0.070 & 0.468 & $0.388 *$ & 0.223 & 6 \\
\hline Mexico & -0.614 & 0.915 & $0.773 *$ & 0.437 & 6 \\
\hline Netherland & 0.434 & 0.294 & $0.415^{* * *}$ & 0.140 & 15 \\
\hline New Zealand & 0.262 & 0.272 & $0.489 * * *$ & 0.129 & 25 \\
\hline Norway & 0.070 & 0.330 & $0.464 * * *$ & 0.157 & 15 \\
\hline Pakistan & -0.878 & 0.550 & 0.123 & 0.262 & 1 \\
\hline Philippines & -0.273 & 0.458 & $0.409 *$ & 0.218 & 7 \\
\hline Poland & -0.053 & 0.785 & 0.346 & 0.374 & 2 \\
\hline Portugal & -0.062 & 0.298 & $0.352 * *$ & 0.142 & 11 \\
\hline Russia & -0.789 & 1.204 & $1.129 *$ & 0.574 & 7 \\
\hline Singapore & 0.092 & 0.355 & 0.281 & 0.169 & 5 \\
\hline South Africa & 0.293 & 0.338 & $0.455^{* *}$ & 0.161 & 14 \\
\hline Spain & 0.362 & 0.369 & $0.689 * * *$ & 0.176 & 23 \\
\hline Sweden & 0.528 & 0.338 & $0.465 * * *$ & 0.161 & 14 \\
\hline Switzerland & $0.709 * *$ & 0.306 & $0.278 *$ & 0.146 & 7 \\
\hline Taiwan & -0.733 & 0.485 & $0.598 * *$ & 0.231 & 12 \\
\hline Thailand & -0.175 & 0.597 & $0.627 * *$ & 0.284 & 9 \\
\hline Turkey & -0.291 & 0.938 & $0.877^{*}$ & 0.447 & 7 \\
\hline UK & 0.302 & 0.298 & $0.400 * *$ & 0.142 & 14 \\
\hline US & $0.546 * *$ & 0.250 & $0.442 * * *$ & 0.119 & 22 \\
\hline
\end{tabular}

Note: Ordinary least square regressions of excess domestic market weekly returns on a constant and excess Australian market weekly return. Alpha, standard error of alpha, beta, standard error of beta are reported. Unadjusted $\mathrm{R}^{2}$ is goodness of fit. *** and *** are significance levels at $1 \%, 5 \%$ and $10 \%$, respectively. 
Table 4: Foreign Bias Measures I

\begin{tabular}{|c|c|c|c|c|c|c|c|c|c|c|c|c|c|c|}
\hline Country & Traditional & $\begin{array}{l}\text { Mean } \\
\text { Variance }\end{array}$ & $\begin{array}{l}\text { Minimum } \\
\text { Variance }\end{array}$ & $\begin{array}{l}\text { Minimum } \\
\text { Variance MP }\end{array}$ & Bayes-Stein & $\begin{array}{l}\text { Bayes-Stein } \\
\text { MP }\end{array}$ & $\begin{array}{l}\text { Bayesian } \\
\text { CS }\end{array}$ & $\begin{array}{l}\text { MPC } \\
\text { CS }\end{array}$ & $\begin{array}{l}\text { Bayesian } \\
0.25\end{array}$ & $\begin{array}{l}\text { MPC } \\
0.25\end{array}$ & $\begin{array}{l}\text { Bayesian } \\
0.50\end{array}$ & $\begin{array}{l}\text { MPC } \\
0.50\end{array}$ & $\begin{array}{l}\text { Bayesian } \\
1.20\end{array}$ & $\begin{array}{l}\text { MPC } \\
1.20\end{array}$ \\
\hline Argentina & -2.016076 & -5.106693 & -4.958220 & -4.961485 & -4.953427 & -4.953885 & -4.771540 & -4.771207 & -4.771030 & -4.770820 & -4.771354 & -4.771179 & -4.771336 & -4.770930 \\
\hline Austria & -2.016758 & -4.635716 & -4.632176 & -4.632047 & -4.653958 & -4.652070 & -4.569490 & -4.569486 & -4.570574 & -4.570812 & -4.570230 & -4.570000 & -4.569642 & -4.569629 \\
\hline Belgium & -2.360332 & -4.898324 & -4.638926 & -4.645165 & -4.585964 & -4.591108 & -4.489557 & -4.489884 & -4.489574 & -4.489687 & -4.490361 & -4.490459 & -4.489657 & -4.489819 \\
\hline Brazil & -2.644344 & -4.246560 & -4.324712 & -4.323636 & -4.292643 & -4.293144 & -4.074774 & -4.076413 & -4.074316 & -4.076103 & -4.075412 & -4.076563 & -4.074404 & -4.075950 \\
\hline Canada & -2.544973 & -4.043254 & -3.918304 & -3.900940 & -3.974766 & -3.969134 & -3.912987 & -3.912372 & -3.913284 & -3.912872 & -3.913367 & -3.912844 & -3.913843 & -3.913230 \\
\hline Chile & -2.985836 & -5.319938 & -5.288514 & -5.290377 & -5.303852 & -5.302391 & -5.052546 & -5.050995 & -5.053316 & -5.052071 & -5.052989 & -5.051683 & -5.053053 & -5.051421 \\
\hline China & -3.482868 & -4.692169 & -4.554379 & -4.556731 & -4.536215 & -4.538055 & -4.365760 & -4.366380 & -4.365847 & -4.366256 & -4.365888 & -4.366501 & -4.366436 & -4.366801 \\
\hline Czech Republic & -2.352571 & -4.654476 & -5.281391 & -5.276162 & -5.308726 & -5.305784 & -5.272076 & -5.269095 & -5.272216 & -5.269416 & -5.271904 & -5.268970 & -5.272185 & -5.269054 \\
\hline Denmark & -2.110165 & -4.194524 & -4.388209 & -4.373246 & -4.469142 & -4.465682 & -4.467468 & -4.466358 & -4.467825 & -4.467060 & -4.466546 & -4.465813 & -4.467693 & -4.466573 \\
\hline Finland & -1.980139 & -4.437487 & -4.463905 & -4.463400 & -4.410095 & -4.415834 & -4.327398 & -4.327910 & -4.327116 & -4.327813 & -4.327678 & -4.328276 & -4.326682 & -4.327250 \\
\hline France & -2.276498 & -3.162318 & -3.488746 & -3.478338 & -3.670161 & -3.657266 & -3.601418 & -3.601048 & -3.601513 & -3.601279 & -3.602080 & -3.601741 & -3.601658 & -3.601252 \\
\hline Germany & -2.240427 & -4.122213 & -3.830687 & -3.837857 & -3.748941 & -3.758541 & -3.712444 & -3.712993 & -3.712035 & -3.712842 & -3.712189 & -3.712382 & -3.712171 & -3.712605 \\
\hline Greece & -2.230711 & -4.721807 & -4.844378 & -4.842171 & -4.838097 & -4.838582 & -4.731665 & -4.732048 & -4.731546 & -4.731854 & -4.732372 & -4.732629 & -4.732476 & -4.732417 \\
\hline Hong Kong & -2.668978 & -3.999699 & -4.294602 & -4.292166 & -4.274600 & -4.276537 & -4.177392 & -4.177968 & -4.177067 & -4.177721 & -4.178363 & -4.179115 & -4.177375 & -4.177974 \\
\hline Hungary & -2.831468 & -5.981121 & -6.070391 & -6.068978 & -6.039339 & -6.042398 & -5.816072 & -5.815535 & -5.816148 & -5.815760 & -5.816019 & -5.815597 & -5.816178 & -5.815626 \\
\hline India & -3.002774 & -4.021407 & -4.613006 & -4.607098 & -4.619659 & -4.618887 & -4.359613 & -4.358942 & -4.359827 & -4.359238 & -4.360255 & -4.359836 & -4.359463 & -4.358687 \\
\hline Indonesia & -2.444120 & -4.748043 & -4.815072 & -4.814248 & -4.812743 & -4.812928 & -4.759481 & -4.758904 & -4.759489 & -4.759011 & -4.759678 & -4.759267 & -4.759393 & -4.758739 \\
\hline Israel & -2.296968 & -4.786141 & -4.687428 & -4.689469 & -4.714151 & -4.711546 & -4.320499 & -4.317769 & -4.321536 & -4.319087 & -4.322451 & -4.320094 & -4.320731 & -4.317876 \\
\hline Italy & -2.211090 & -4.443108 & -4.185478 & -4.190771 & -4.152359 & -4.155713 & -4.112240 & -4.113239 & -4.111732 & -4.112670 & -4.112401 & -4.113189 & -4.112404 & -4.112962 \\
\hline Japan & -2.269177 & -3.741074 & -3.330664 & -3.341329 & -3.365868 & -3.364568 & -3.365868 & -3.365632 & -3.365777 & -3.365844 & -3.365188 & -3.365037 & -3.365608 & -3.365412 \\
\hline Korea & -2.403935 & -4.076333 & -4.150532 & -4.149508 & -4.130555 & -4.132195 & -4.096579 & -4.096708 & -4.096717 & -4.096859 & -4.096838 & -4.097223 & -4.096650 & -4.096901 \\
\hline Malaysia & -2.599988 & -4.794575 & -4.778484 & -4.778840 & -4.771015 & -4.771679 & -4.686530 & -4.686538 & -4.685709 & -4.685950 & -4.686142 & -4.685901 & -4.685743 & -4.685632 \\
\hline Mexico & -2.644359 & -4.001340 & -4.806935 & -4.800402 & -4.772233 & -4.775455 & -4.577466 & -4.577664 & -4.577086 & -4.577654 & -4.577371 & -4.577886 & -4.576817 & -4.577249 \\
\hline Netherland & -2.197948 & -4.420967 & -4.109049 & -4.115108 & -4.066052 & -4.068911 & -4.040849 & -4.040912 & -4.041060 & -4.041318 & -4.040493 & -4.040486 & -4.040990 & -4.040939 \\
\hline New Zealand & -1.225271 & -4.151024 & -3.944715 & -3.948723 & -4.000485 & -3.994401 & -3.994010 & -3.993931 & -3.993989 & -3.994076 & -3.993539 & -3.993536 & -3.994137 & -3.993935 \\
\hline Norway & -2.132087 & -4.449249 & -4.467125 & -4.467139 & -4.431058 & -4.434488 & -4.358668 & -4.359744 & -4.358755 & -4.360092 & -4.357750 & -4.358484 & -4.359153 & -4.359789 \\
\hline Pakistan & -2.714755 & -5.842225 & -5.760896 & -5.762464 & -5.774832 & -5.773309 & -5.775646 & -5.773285 & -5.775471 & -5.773282 & -5.775117 & -5.772621 & -5.775125 & -5.772750 \\
\hline Philippines & -2.155566 & -5.051855 & -4.899291 & -4.902600 & -4.882817 & -4.884557 & -4.821720 & -4.822859 & -4.821944 & -4.822740 & -4.820771 & -4.821589 & -4.821497 & -4.822590 \\
\hline Poland & -3.181381 & -5.841498 & -5.720765 & -5.722825 & -5.718764 & -5.718894 & -5.467533 & -5.466042 & -5.467078 & -5.465877 & -5.467766 & -5.466509 & -5.467523 & -5.466098 \\
\hline Portugal & -2.115590 & -5.074413 & -4.828003 & -4.833128 & -4.844343 & -4.842937 & -4.845032 & -4.843047 & -4.844747 & -4.843037 & -4.845075 & -4.843038 & -4.845050 & -4.843080 \\
\hline Russia & -2.719367 & -4.411386 & -4.480568 & -4.479523 & -4.472851 & -4.473631 & -4.311723 & -4.309468 & -4.311028 & -4.308498 & -4.311422 & -4.308717 & -4.311268 & -4.308577 \\
\hline Singapore & -2.211222 & -4.304283 & -4.336355 & -4.335990 & -4.368337 & -4.365546 & -4.326790 & -4.327193 & -4.326830 & -4.327600 & -4.326619 & -4.326771 & -4.327183 & -4.327396 \\
\hline South Africa & -2.777999 & -4.746739 & -4.556045 & -4.559548 & -4.577356 & -4.575322 & -4.511198 & -4.509713 & -4.511054 & -4.509772 & -4.510706 & -4.509307 & -4.511339 & -4.509956 \\
\hline Spain & -2.644091 & -4.082993 & -4.258304 & -4.244900 & -4.228458 & -4.231130 & -4.154144 & -4.155355 & -4.154161 & -4.154786 & -4.154161 & -4.155493 & -4.153851 & -4.155075 \\
\hline Sweden & -2.299313 & -4.307236 & -4.386427 & -4.387097 & -4.307375 & -4.317893 & -4.307375 & -4.309327 & -4.307147 & -4.309366 & -4.306716 & -4.308579 & -4.307514 & -4.309414 \\
\hline Switzerland & -2.119909 & -3.795720 & -3.687678 & -3.675784 & -3.755953 & -3.749584 & -3.723198 & -3.722977 & -3.723045 & -3.722836 & -3.723715 & -3.723416 & -3.723522 & -3.723086 \\
\hline Taiwan & -2.351021 & -4.300365 & -4.212693 & -4.214284 & -4.200824 & -4.201933 & -4.194562 & -4.194291 & -4.193857 & -4.193805 & -4.194166 & -4.194642 & -4.194214 & -4.193774 \\
\hline Thailand & -2.316680 & -4.945784 & -4.811110 & -4.814083 & -4.793791 & -4.795051 & -4.663771 & -4.665095 & -4.663619 & -4.6649993 & -4.663309 & -4.664546 & -4.663034 & -4.664192 \\
\hline Turkey & -2.501194 & -4.844738 & -4.864610 & -4.864364 & -4.844701 & -4.846718 & -4.698686 & -4.700512 & -4.699593 & -4.701436 & -4.699185 & -4.700940 & -4.698855 & -4.700627 \\
\hline UK & -2.536689 & -4.00434 & -3.656667 & -3.664537 & -3.721304 & -3.715921 & -3.647527 & -3.646653 & -3.647689 & -3.646737 & -3.647148 & -3.646294 & -3.647543 & -3.646463 \\
\hline US & -2.875388 & -3.368226 & -3.255845 & -3.258288 & -3.321762 & -3.315857 & -3.320303 & -3.318829 & -3.320328 & -3.319205 & -3.320229 & -3.318929 & -3.320431 & -3.319012 \\
\hline
\end{tabular}

Note: Foreign bias measures are average foreign bias values over the years 2002 to 2011 . Mutual fund equity holdings data is from Morningstar. Traditional is average foreign bias measure computed in ICAPM framework. Mean Variance is average Mean Variance foreign bias. Minimum Variance is average Minimum Variance foreign bias. Minimum Variance MP is average Multi-Prior (data based) foreign bias. BayesStein is average Bayes-Stein foreign bias. Bayes-Stein MP is average Multi-Prior (Bayes-Stein) foreign bias. Bayesian CS is average Bayesian (country standard error) foreign bias. MPC CS is average Multi-Prior (country standard error) foreign bias. Bayesian 0.25 is average Bayesian ( 0.25 standard error) foreign bias, MPC 0.25 is average Multi-Prior ( 0.25 standard error) foreign bias. Bayesian 0.5 is average Bayesian ( 0.5 standard error) foreign bias, MPC 0.5 is average Multi-Prior ( 0.5 standard error) foreign bias. Bayesian 1.2 is average Bayesian (1.2 standard error) foreign bias, MPC 1.2 is average Multi-Prior (1.2 standard error) foreign bias. Refer Appendix Table A-1 for definition of various measures of foreign bias. 
Table 4: Foreign Bias Measures II

\begin{tabular}{|c|c|c|c|c|c|c|c|c|c|c|c|c|c|c|}
\hline Country & Traditional & $\begin{array}{l}\text { Mean } \\
\text { Variance }\end{array}$ & $\begin{array}{l}\text { Minimum } \\
\text { Variance }\end{array}$ & $\begin{array}{l}\text { Minimum } \\
\text { Variance MP }\end{array}$ & Bayes-Stein & $\begin{array}{l}\text { Bayes-Stein } \\
\text { MP }\end{array}$ & $\begin{array}{l}\text { Bayesian } \\
\text { CS }\end{array}$ & $\begin{array}{l}\text { MPC } \\
\text { CS }\end{array}$ & $\begin{array}{l}\text { Bayesian } \\
0.25\end{array}$ & $\begin{array}{l}\text { MPC } \\
0.25\end{array}$ & $\begin{array}{l}\text { Bayesian } \\
0.50\end{array}$ & $\begin{array}{l}\text { MPC } \\
0.50\end{array}$ & $\begin{array}{l}\text { Bayesian } \\
1.20\end{array}$ & $\begin{array}{l}\text { MPC } \\
1.20\end{array}$ \\
\hline Argentina & -1.723197 & -4.426576 & -4.546717 & -4.539609 & -4.510994 & -4.516848 & -3.232956 & -3.233158 & -3.234029 & -3.234729 & -3.233716 & -3.234694 & -3.233627 & -3.234234 \\
\hline Austria & -1.080530 & -3.643555 & -3.714219 & -3.712786 & -3.748975 & -3.744383 & -3.232956 & -3.233158 & -3.234029 & -3.234729 & -3.233716 & -3.234694 & -3.233627 & -3.234234 \\
\hline Belgium & -0.993933 & -3.530317 & -3.290588 & -3.294231 & -3.227324 & -3.236626 & -3.145207 & -3.145522 & -3.145354 & -3.146059 & -3.145616 & -3.146424 & -3.145253 & -3.145786 \\
\hline Brazil & -1.214634 & -2.969921 & -3.041476 & -3.040693 & -3.008741 & -3.013020 & -2.979571 & -2.980345 & -2.979295 & -2.980446 & -2.979739 & -2.980923 & -2.979372 & -2.980469 \\
\hline Canada & -0.939539 & -2.699353 & -2.772951 & -2.774173 & -2.740246 & -2.743863 & -2.423665 & -2.423464 & -2.423502 & -2.423877 & -2.423759 & -2.423614 & -2.423744 & -2.423625 \\
\hline Chile & -1.703566 & -4.193249 & -4.275790 & -4.270842 & -4.255694 & -4.258993 & -3.232956 & -3.233158 & -3.234029 & -3.234729 & -3.233716 & -3.234694 & -3.233627 & -3.234234 \\
\hline China & -1.751747 & -3.128929 & -3.057274 & -3.059063 & -3.035357 & -3.038616 & -3.029262 & -3.030458 & -3.029798 & -3.031093 & -3.029753 & -3.031138 & -3.029553 & -3.030954 \\
\hline Czech Republic & -1.476821 & -3.891504 & -4.351947 & -4.345293 & -4.348830 & -4.350206 & -3.232956 & -3.233158 & -3.234029 & -3.234729 & -3.233716 & -3.234694 & -3.233627 & -3.234234 \\
\hline Denmark & -0.889867 & -2.888342 & -3.199680 & -3.186961 & -3.286253 & -3.276104 & -3.220322 & -3.220144 & -3.221047 & -3.221146 & -3.220893 & -3.221213 & -3.220744 & -3.220807 \\
\hline Finland & -0.878157 & -3.230904 & -3.306792 & -3.305164 & -3.256507 & -3.263144 & -3.185227 & -3.185824 & -3.186027 & -3.186873 & -3.185750 & -3.187068 & -3.185697 & -3.186546 \\
\hline France & -0.855942 & -2.699353 & -2.772951 & -2.774173 & -2.740246 & -2.743863 & -2.139535 & -2.139558 & -2.140041 & -2.139824 & -2.140363 & -2.140199 & -2.139669 & -2.139376 \\
\hline Germany & -0.864487 & -2.760418 & -2.772951 & -2.774173 & -2.740246 & -2.743863 & -2.292879 & -2.293532 & -2.292661 & -2.293678 & -2.292897 & -2.293341 & -2.292732 & -2.293326 \\
\hline Greece & -1.057301 & -3.384380 & -3.603257 & -3.600284 & -3.596894 & -3.597869 & -3.232956 & -3.233158 & -3.234029 & -3.234729 & -3.233716 & -3.234694 & -3.233627 & -3.234234 \\
\hline Hong Kong & -0.871396 & -2.699353 & -2.772951 & -2.774173 & -2.740246 & -2.743863 & -2.385176 & -2.386155 & -2.385288 & -2.386534 & -2.385767 & -2.386938 & -2.385265 & -2.386193 \\
\hline Hungary & -1.157900 & -4.042005 & -4.381498 & -4.377802 & -4.348398 & -4.352908 & -3.232956 & -3.233158 & -3.234029 & -3.234729 & -3.233716 & -3.234694 & -3.233627 & -3.234234 \\
\hline India & -1.036579 & -2.699353 & -2.836486 & -2.833344 & -2.830179 & -2.830946 & -2.786996 & -2.786272 & -2.786818 & -2.786098 & -2.786922 & -2.786240 & -2.786863 & -2.786001 \\
\hline Indonesia & -1.074181 & -3.332871 & -3.393758 & -3.392825 & -3.391613 & -3.392056 & -3.228909 & -3.228631 & -3.230203 & -3.230488 & -3.229579 & -3.229859 & -3.229906 & -3.229942 \\
\hline Israel & -1.326256 & -3.879328 & -3.775506 & -3.779523 & -3.797002 & -3.795096 & -3.232956 & -3.233158 & -3.234029 & -3.234729 & -3.233716 & -3.234694 & -3.233627 & -3.234234 \\
\hline Italy & -0.926313 & -2.923998 & -2.818350 & -2.821052 & -2.784156 & -2.788083 & -2.740865 & -2.741846 & -2.740648 & -2.741864 & -2.740782 & -2.741941 & -2.740659 & -2.741513 \\
\hline Japan & -0.869626 & -2.699353 & -2.772951 & -2.774173 & -2.740246 & -2.743863 & -1.856810 & -1.856688 & -1.856597 & -1.856910 & -1.856321 & -1.856452 & -1.856988 & -1.856948 \\
\hline Korea & -0.867305 & -2.734464 & -2.795339 & -2.796303 & -2.763827 & -2.767611 & -2.622151 & -2.623935 & -2.622151 & -2.624223 & -2.622085 & -2.623823 & -2.622235 & -2.623927 \\
\hline Malaysia & -1.311185 & -3.579597 & -3.575996 & -3.576579 & -3.563480 & -3.565442 & -3.228917 & -3.228864 & -3.229843 & -3.230261 & -3.229380 & -3.230004 & -3.229388 & -3.229710 \\
\hline Mexico & -1.193112 & -2.441711 & -3.326666 & -3.319336 & -3.295814 & -3.299456 & -3.188810 & -3.188461 & -3.188991 & -3.188910 & -3.188569 & -3.188496 & -3.188901 & -3.188689 \\
\hline Netherland & -0.855942 & -2.723850 & -2.772951 & -2.774173 & -2.740246 & -2.743863 & -2.136016 & -2.136185 & -2.136002 & -2.136465 & -2.135591 & -2.135727 & -2.136036 & -2.136130 \\
\hline New Zealand & -0.855942 & -2.810672 & -2.873928 & -2.874700 & -2.850110 & -2.852921 & -2.688128 & -2.688132 & -2.687964 & -2.688174 & -2.687628 & -2.687672 & -2.688103 & -2.688023 \\
\hline Norway & -0.962114 & -3.332357 & -3.350112 & -3.349721 & -3.315530 & -3.320253 & -3.215046 & -3.215455 & -3.215989 & -3.216797 & -3.215483 & -3.216392 & -3.215646 & -3.216303 \\
\hline Pakistan & -1.577326 & -4.426576 & -4.546717 & -4.539609 & -4.510994 & -4.516848 & -4.512722 & -4.515030 & -4.513124 & -4.516650 & -4.515347 & -4.514657 & -4.512678 & -4.513535 \\
\hline Philippines & -1.149492 & -4.129599 & -4.003698 & -4.006747 & -3.983742 & -3.986675 & -3.232956 & -3.233158 & -3.234029 & -3.234729 & -3.233716 & -3.234694 & -3.233627 & -3.234234 \\
\hline Poland & -1.751747 & -4.426576 & -4.546717 & -4.539609 & -4.510994 & -4.516848 & -4.512722 & -4.515030 & -4.513124 & -4.516650 & -4.515347 & -4.514657 & -4.512678 & -4.513535 \\
\hline Portugal & -1.189877 & -4.169696 & -3.911076 & -3.912830 & -3.926886 & -3.924938 & -3.927539 & -3.925497 & -3.927399 & -3.925595 & -3.927627 & -3.925493 & -3.927709 & -3.925595 \\
\hline Russia & -1.374135 & -3.060083 & -3.128822 & -3.127867 & -3.123059 & -3.123973 & -3.120902 & -3.119361 & -3.121479 & -3.120237 & -3.121382 & -3.120002 & -3.121257 & -3.119766 \\
\hline Singapore & -0.861435 & -2.829241 & -2.831042 & -2.832675 & -2.826848 & -2.827039 & -2.826053 & -2.826905 & -2.825277 & -2.826525 & -2.825465 & -2.826586 & -2.825307 & -2.826365 \\
\hline South Africa & -1.336111 & -3.461805 & -3.238173 & -3.242166 & -3.261560 & -3.258874 & -3.128035 & -3.127264 & -3.128611 & -3.128219 & -3.128216 & -3.127884 & -3.128487 & -3.127933 \\
\hline Spain & -1.036579 & -2.728293 & -2.890351 & -2.883251 & -2.838757 & -2.846567 & -2.836947 & -2.838923 & -2.836687 & -2.838935 & -2.836723 & -2.838586 & -2.836347 & -2.838356 \\
\hline Sweden & -0.898283 & -2.948105 & -2.953181 & -2.953357 & -2.874110 & -2.884068 & -2.872349 & -2.874320 & -2.872275 & -2.874639 & -2.871782 & -2.873799 & -2.872389 & -2.874345 \\
\hline Switzerland & -0.855942 & -2.699353 & -2.772951 & -2.774173 & -2.740246 & -2.743863 & -2.359269 & -2.358585 & -2.359320 & -2.358838 & -2.359231 & -2.358441 & -2.359313 & -2.358337 \\
\hline $\begin{array}{l}\text { Taiwan } \\
\text {. }\end{array}$ & -0.856684 & -2.802377 & -2.774100 & -2.774798 & -2.756777 & -2.759379 & -2.755787 & -2.757069 & -2.756500 & -2.758115 & -2.757390 & -2.758906 & -2.755430 & -2.757032 \\
\hline Thailand & -0.945433 & -3.531680 & -3.425767 & -3.427909 & -3.409141 & -3.411564 & -3.204913 & -3.205449 & -3.206038 & -3.206982 & -3.205785 & -3.206736 & -3.206031 & -3.206804 \\
\hline Turkey & -1.313896 & -3.606550 & -3.638652 & -3.638355 & -3.619414 & -3.621834 & -3.232956 & -3.233158 & -3.234029 & -3.234729 & -3.233716 & -3.234694 & -3.233627 & -3.234234 \\
\hline UK & -0.855942 & -2.699353 & -2.772951 & -2.774173 & -2.740246 & -2.743863 & -1.772712 & -1.772193 & -1.772566 & -1.772060 & -1.772379 & -1.771674 & -1.772721 & -1.772188 \\
\hline US & -0.854542 & -2.599153 & -2.673252 & -2.684276 & -2.693146 & -2.643245 & -1.708886 & -1.708210 & -1.709064 & -1.707977 & -1.708886 & -1.707943 & -1.708886 & -1.708084 \\
\hline
\end{tabular}

Note: Foreign bias measures are average foreign bias values over the years 2002 to 2011 .Foreign equity holdings data is from CPIS. Traditional is average foreign bias measure computed in ICAPM framework. Mean Variance is average Mean Variance foreign bias. Minimum Variance is average Minimum Variance foreign bias. Minimum Variance MP is average Multi-Prior (data based) foreign bias. Bayes-Stein is average Bayes-Stein foreign bias. Bayes-Stein MP is average Multi-Prior (Bayes-Stein) foreign bias. Bayesian CS is average Bayesian (country standard error) foreign bias. MPC CS is average Multi-Prior (country standard error) foreign bias. Bayesian 0.25 is average Bayesian ( 0.25 standard error) foreign bias, MPC 0.25 is average Multi-Prior $(0.25$ standard error) foreign bias. Bayesian 0.5 is average Bayesian ( 0.5 standard error) Appendix Table A-1 for definition of various measures of foreign bias. 
Table 5: Determinants of foreign bias I

\begin{tabular}{|c|c|c|c|c|c|c|c|c|c|c|c|c|c|c|c|c|}
\hline & (1) & (2) & (3) & (4) & (5) & (6) & (7) & (8) & (9) & (10) & (11) & (12) & (13) & (14) & (15) & (16) \\
\hline TR & $\begin{array}{l}-0.346 \\
(0.290)\end{array}$ & $\begin{array}{l}-0.315 \\
(0.171)\end{array}$ & $\begin{array}{l}-0.236 \\
(0.501)\end{array}$ & $\begin{array}{l}-0.160 \\
(0.467)\end{array}$ & $\begin{array}{l}0.220^{* * *} \\
(0.025)\end{array}$ & $\begin{array}{l}-0.078 \\
(0.778)\end{array}$ & $\begin{array}{l}-0.276 \\
(0.432)\end{array}$ & $\begin{array}{l}0.181 * * \\
(0.046)\end{array}$ & $\begin{array}{l}0.141 \\
(0.176)\end{array}$ & $\begin{array}{l}0.303 * * * \\
(0.005)\end{array}$ & $\begin{array}{l}-0.100 \\
(0.452)\end{array}$ & $\begin{array}{l}-0.110 \\
(0.490)\end{array}$ & $\begin{array}{l}-0.227 \\
(0.331)\end{array}$ & $\begin{array}{l}-0.093 \\
(0.353)\end{array}$ & $\begin{array}{l}-0.079 \\
(0.241)\end{array}$ & $\begin{array}{l}-0.066 \\
(0.633)\end{array}$ \\
\hline GDPC & $\begin{array}{l}0.288^{* * * *} \\
(0.000)\end{array}$ & $\begin{array}{l}0.154 * * * \\
(0.000)\end{array}$ & $\begin{array}{l}0.620 \text { **** } \\
(0.000)\end{array}$ & $\begin{array}{l}0.510^{* * * *} \\
(0.004)\end{array}$ & $\begin{array}{l}0.216^{*} \\
(0.078)\end{array}$ & $\begin{array}{l}0.481 * * * \\
(0.009)\end{array}$ & $\begin{array}{l}0.607 * * * \\
(0.004)\end{array}$ & $\begin{array}{l}0.318 * * * \\
(0.004)\end{array}$ & $\begin{array}{l}0.212^{*} \\
(0.071)\end{array}$ & $\begin{array}{l}0.401 * * * \\
(0.003)\end{array}$ & $\begin{array}{l}0.373^{* * * *} \\
(0.000)\end{array}$ & $\begin{array}{l}0.335^{* * * *} \\
(0.000)\end{array}$ & $\begin{array}{l}0.206^{* * *} \\
(0.000)\end{array}$ & $\begin{array}{l}0.282 * * * \\
(0.000)\end{array}$ & $\begin{array}{l}0.094 * * \\
(0.036)\end{array}$ & $\begin{array}{l}0.114 * * \\
(0.030)\end{array}$ \\
\hline VOL & $\begin{array}{l}-0.709 * * \\
(0.017)\end{array}$ & $\begin{array}{l}-0.639^{* *} \\
(0.021)\end{array}$ & $\begin{array}{l}-1.116^{* * *} \\
(0.028)\end{array}$ & $\begin{array}{l}-1.172 * * * \\
(0.005)\end{array}$ & $\begin{array}{l}-0.664 * * \\
(0.039)\end{array}$ & $\begin{array}{l}-1.032 * * * \\
(0.000)\end{array}$ & $\begin{array}{l}-1.057 * * \\
(0.027)\end{array}$ & $\begin{array}{l}-0.601 * * \\
(0.011)\end{array}$ & $\begin{array}{l}-0.913 * * * \\
(0.001)\end{array}$ & $\begin{array}{l}-0.610^{* * *} \\
(0.048)\end{array}$ & $\begin{array}{l}-1.165^{* * *} \\
(0.000)\end{array}$ & $\begin{array}{l}-0.776 * * \\
(0.037)\end{array}$ & $\begin{array}{l}-0.622 * * * \\
(0.004)\end{array}$ & $\begin{array}{l}-0.519 * * \\
(0.016)\end{array}$ & $\begin{array}{l}-0.157^{*} \\
(0.051)\end{array}$ & $\begin{array}{l}-0.281 * * \\
(0.023)\end{array}$ \\
\hline MGDP & $\begin{array}{l}0.128^{*} \\
(0.056)\end{array}$ & & & & & & & & & & & & & & & \\
\hline TURN & & $\begin{array}{l}0.085^{*} \\
(0.059)\end{array}$ & & & & & & & & & & & & & & \\
\hline LAN & & & $\begin{array}{l}1.131 \text { *** } \\
(0.008)\end{array}$ & & & & & & & & & & & & & \\
\hline DIS & & & & $\begin{array}{l}-0.600 * * * \\
(0.021)\end{array}$ & & & & & & & & & & & & \\
\hline INF & & & & & $\begin{array}{l}-0.365^{* * * *} \\
(0.000)\end{array}$ & & & & & & & & & & & \\
\hline COR & & & & & & $\begin{array}{l}1.448^{* *} \\
(0.039)\end{array}$ & & & & & & & & & & \\
\hline LEG & & & & & & & $\begin{array}{l}1.013^{* *} \\
(0.010)\end{array}$ & & & & & & & & & \\
\hline $\mathrm{TC}$ & & & & & & & & $\begin{array}{l}0.257 * * \\
(0.045)\end{array}$ & & & & & & & & \\
\hline TRAN & & & & & & & & & $\begin{array}{l}0.028 \\
(0.716)\end{array}$ & & & & & & & \\
\hline GFC & & & & & & & & & & $\begin{array}{l}-0.296 * * * \\
(0.000)\end{array}$ & & & & & & \\
\hline SIZ & & & & & & & & & & & $\begin{array}{l}-0.029 * * * \\
(0.000)\end{array}$ & $\begin{array}{l}-0.023 * * * \\
(0.009)\end{array}$ & $\begin{array}{l}-0.019 * * * \\
(0.000)\end{array}$ & $\begin{array}{l}-0.012 * * * \\
(0.001)\end{array}$ & $\begin{array}{l}-0.019 * * * * \\
(0.000)\end{array}$ & $\begin{array}{l}-0.025 * * * \\
(0.000)\end{array}$ \\
\hline AR & & & & & & & & & & & & $\begin{array}{l}0.091 * * * \\
(0.002)\end{array}$ & & & & \\
\hline PB & & & & & & & & & & & & & $\begin{array}{l}0.249 * * \\
(0.000)\end{array}$ & & & \\
\hline PC & & & & & & & & & & & & & & $\begin{array}{l}-0.213 * * \\
(0.011)\end{array}$ & & \\
\hline PE & & & & & & & & & & & & & & & $\begin{array}{l}0.454 * * * \\
(0.000)\end{array}$ & \\
\hline PS & & & & & & & & & & & & & & & & $\begin{array}{l}-0.181 \text { *** } \\
(0.009)\end{array}$ \\
\hline Obs. & 1034 & 1034 & 1034 & 1034 & 1033 & 1034 & 1034 & 1034 & 1030 & 1033 & 1034 & 528 & 1714 & 1478 & 1700 & 1710 \\
\hline $\begin{array}{l}\text { Wald } \\
\mathrm{Chi}^{2}\end{array}$ & $\begin{array}{l}131.58 \text { *** } \\
(0.000)\end{array}$ & $\begin{array}{l}112.10^{* * * *} \\
(0.000)\end{array}$ & $\begin{array}{l}96.56 \text { *** } \\
(0.000)\end{array}$ & $\begin{array}{l}93.05^{* * * *} \\
(0.000)\end{array}$ & $\begin{array}{l}121.33 \text { *** } \\
(0.000)\end{array}$ & $\begin{array}{l}95.09 * * * \\
(0.000)\end{array}$ & 83.09 *** & $130.64 * * *$ & $100.96^{* * * *}$ & $176.22 * * *$ & $157.16^{* * * *}$ & $92.20^{* * * *}$ & $178.65^{* * * *}$ & 459.60 *** & 610.61 *** & $511.01 * * *$ \\
\hline $\mathrm{m} 1$ & $-2.189 * *$ & $-2.215^{* *}$ & $-1.952 * *$ & $-2.514 * *$ & $-2.027 * *$ & $-2.324 * *$ & $-1.963 * *$ & $-2.631 * * *$ & $-2.633^{* * *}$ & $-2.212 * *$ & $-2.510^{* *}$ & $-2.053^{* *}$ & $-2.316^{* *}$ & $-2.112 * *$ & $-2.094 * *$ & $-2.010^{* *}$ \\
\hline & $(0.035)$ & $(0.026)$ & $(0.059)$ & $(0.011)$ & $(0.042)$ & $(0.020)$ & $(0.049)$ & $(0.008)$ & $(0.008)$ & $(0.026)$ & $(0.012)$ & $(0.040)$ & $(0.020)$ & $(0.026)$ & $(0.036)$ & $(0.044)$ \\
\hline $\mathrm{m} 2$ & $\begin{array}{l}-2.009 \\
(0.108)\end{array}$ & $\begin{array}{l}-2.009 \\
(0.445)\end{array}$ & $\begin{array}{l}-0.907 \\
(0.597)\end{array}$ & $\begin{array}{l}-2.140 \\
(0.306)\end{array}$ & $\begin{array}{l}-1.976 \\
(0.543)\end{array}$ & $\begin{array}{l}-2.102 \\
(0.639)\end{array}$ & $\begin{array}{l}-1.145 \\
(0.569)\end{array}$ & $\begin{array}{l}-1.153 \\
(0.216)\end{array}$ & $\begin{array}{l}-1.169 \\
(0.413)\end{array}$ & $\begin{array}{l}-1.169 \\
(0.363)\end{array}$ & $\begin{array}{l}-2.102 \\
(0.639)\end{array}$ & $\begin{array}{l}-1.644 \\
(0.100)\end{array}$ & $\begin{array}{l}0.295 \\
(0.767)\end{array}$ & $\begin{array}{l}1.503 \\
(0.614)\end{array}$ & $\begin{array}{l}-1.023 \\
(0.403)\end{array}$ & $\begin{array}{l}0.845 \\
(0.397)\end{array}$ \\
\hline
\end{tabular}

Note: Traditional home bias is dependent variable. Arellano-Bover/Blundell Bond Estimation with lags(1) and AR(2) tests. m1, m2: Arellano Bond test for no auto correlation. Obs.: Observations. Lag value of traditional home bias is not reported. Constant is not reported. P-values in brackets. Refer Appendix Table A.1 for definition of Traditional home bias, TR(Trade), GDPC (GDP per capita), VOL (Exchange rate (Global financial crisis), SIZ (Size), AR (Annual return), PB (Price Book ratio), PC (Price Cash flow ratio), PE (Price Earnings ratio), PS (Price Sales ratio). ***** and * represent significance level at 1,5 and 10 percent respectively. 
Table 6: Determinants of foreign bias II

\begin{tabular}{|c|c|c|c|c|c|c|c|c|c|c|c|c|c|c|c|c|}
\hline & (1) & (2) & (3) & (4) & (5) & (6) & (7) & (8) & (9) & (10) & (11) & (12) & (13) & (14) & (15) & (16) \\
\hline TR & $\begin{array}{l}-0.047 \\
(0.731)\end{array}$ & $\begin{array}{l}-0.198 \\
(0.510)\end{array}$ & $\begin{array}{l}-0.038 \\
(0.771)\end{array}$ & $\begin{array}{l}-0.085 \\
(0.522)\end{array}$ & $\begin{array}{l}-0.055 \\
(0.631)\end{array}$ & $\begin{array}{l}-0.091 \\
(0.484)\end{array}$ & $\begin{array}{l}-0.144 \\
(0.310)\end{array}$ & $\begin{array}{l}-0.084 \\
(0.508)\end{array}$ & $\begin{array}{l}-0.077 \\
(0.560)\end{array}$ & $\begin{array}{l}-0.126 \\
(0.334)\end{array}$ & $\begin{array}{l}-0.034 \\
(0.788)\end{array}$ & $\begin{array}{l}-0.115 \\
(0.377)\end{array}$ & $\begin{array}{l}0.184 * * \\
(0.044)\end{array}$ & $\begin{array}{l}-0.040 \\
(0.956)\end{array}$ & $\begin{array}{l}0.055 \\
(0.434)\end{array}$ & $\begin{array}{l}-0.069 \\
(0.607)\end{array}$ \\
\hline FOR & $\begin{array}{l}0.254 * \\
(0.077)\end{array}$ & $\begin{array}{l}0.049^{*} \\
(0.065)\end{array}$ & $\begin{array}{l}0.402 * * \\
(0.011)\end{array}$ & $\begin{array}{l}0.284 * \\
(0.061)\end{array}$ & $\begin{array}{l}0.204 * \\
(0.081)\end{array}$ & $\begin{array}{l}0.329 * * \\
(0.029)\end{array}$ & $\begin{array}{l}0.348^{* *} \\
(0.026)\end{array}$ & $\begin{array}{l}0.327 * * \\
(0.031)\end{array}$ & $\begin{array}{l}0.350^{* *} \\
(0.020)\end{array}$ & $\begin{array}{l}0.063 * \\
(0.071)\end{array}$ & $\begin{array}{l}0.311^{* *} \\
(0.023)\end{array}$ & $\begin{array}{l}0.224 * \\
(0.076)\end{array}$ & $\begin{array}{l}0.312 * * * \\
(0.007)\end{array}$ & $\begin{array}{l}0.151^{* *} \\
(0.039)\end{array}$ & $\begin{array}{l}0.038^{* * *} \\
(0.043)\end{array}$ & $\begin{array}{l}0.336^{* *} \\
(0.025)\end{array}$ \\
\hline VOL & $\begin{array}{l}-0.786^{* * * *} \\
(0.002)\end{array}$ & $\begin{array}{l}-0.892 * * * \\
(0.000)\end{array}$ & $\begin{array}{l}-0.746^{* * * *} \\
(0.007)\end{array}$ & $\begin{array}{l}-1.222 * * * \\
(0.000)\end{array}$ & $\begin{array}{l}-0.881 \text { *** } \\
(0.001)\end{array}$ & $\begin{array}{l}-1.031 \text { *** } \\
(0.000)\end{array}$ & $\begin{array}{l}-0.850 * * * \\
(0.002)\end{array}$ & $\begin{array}{l}-0.965^{* * *} \\
(0.000)\end{array}$ & $\begin{array}{l}-0.940 * * * \\
(0.000)\end{array}$ & $\begin{array}{l}-0.613 * * \\
(0.021)\end{array}$ & $\begin{array}{l}-0.754 * * * \\
(0.002)\end{array}$ & $\begin{array}{l}-0.923 * * * \\
(0.006)\end{array}$ & $\begin{array}{l}-0.102 * \\
(0.072)\end{array}$ & $\begin{array}{l}-0.825^{* * *} \\
(0.000)\end{array}$ & $\begin{array}{l}-0.401 * * \\
(0.043)\end{array}$ & $\begin{array}{l}-0.958 * * * \\
(0.000)\end{array}$ \\
\hline MGDP & $\begin{array}{l}0.163 * * * \\
(0.003)\end{array}$ & & & & & & & & & & & & & & & \\
\hline TURN & & $\begin{array}{l}0.120^{*} \\
(0.069)\end{array}$ & & & & & & & & & & & & & & \\
\hline LAN & & & $\begin{array}{l}0.390 * * \\
(0.020)\end{array}$ & & & & & & & & & & & & & \\
\hline DIS & & & & $\begin{array}{l}-0.560^{*} \\
(0.061)\end{array}$ & & & & & & & & & & & & \\
\hline INF & & & & & $\begin{array}{l}-0.207 * * * \\
(0.003)\end{array}$ & & & & & & & & & & & \\
\hline COR & & & & & & $\begin{array}{l}0.235 \\
(0.551)\end{array}$ & & & & & & & & & & \\
\hline LEG & & & & & & & $\begin{array}{l}0.466^{* *} \\
(0.011)\end{array}$ & & & & & & & & & \\
\hline $\mathrm{TC}$ & & & & & & & & $\begin{array}{l}0.163^{* *} \\
(0.012)\end{array}$ & & & & & & & & \\
\hline TRAN & & & & & & & & & $\begin{array}{l}0.072 \\
(0.336)\end{array}$ & & & & & & & \\
\hline QUA & & & & & & & & & & $\begin{array}{l}0.459 * * * \\
(0.002)\end{array}$ & & & & & & \\
\hline GFC & & & & & & & & & & & $\begin{array}{l}-0.237 * * * \\
(0.000)\end{array}$ & & & & & \\
\hline SIZ & $\begin{array}{l}-0.022 * * * \\
(0.002)\end{array}$ & $\begin{array}{l}-0.023^{* * *} * \\
(0.000)\end{array}$ & $\begin{array}{l}-0.032 * * * \\
(0.000)\end{array}$ & $\begin{array}{l}-0.025 * * * \\
(0.001)\end{array}$ & $\begin{array}{l}-0.020^{* * * *} \\
(0.003)\end{array}$ & $\begin{array}{l}-0.025^{* * *} \\
(0.001)\end{array}$ & $\begin{array}{l}-0.035^{* * *} \\
(0.000)\end{array}$ & $\begin{array}{l}-0.024 * * * \\
(0.001)\end{array}$ & $\begin{array}{l}-0.023 * * * \\
(0.002)\end{array}$ & $\begin{array}{l}-0.024 * * * \\
(0.001)\end{array}$ & $\begin{array}{l}-0.021 * * * \\
(0.003)\end{array}$ & $\begin{array}{l}-0.017 * \\
(0.073)\end{array}$ & $\begin{array}{l}-0.002 * \\
(0.053)\end{array}$ & $\begin{array}{l}-0.013 * * * \\
(0.000)\end{array}$ & $\begin{array}{l}-0.013 * * * \\
(0.000)\end{array}$ & $\begin{array}{l}-0.024 * * * \\
(0.001)\end{array}$ \\
\hline AR & & & & & & & & & & & & $\begin{array}{l}0.084 * * * \\
(0.008)\end{array}$ & & & & \\
\hline PB & & & & & & & & & & & & & $\begin{array}{l}0.123^{*} \\
(0.069)\end{array}$ & & & \\
\hline PC & & & & & & & & & & & & & & $\begin{array}{l}-0.265 * * * \\
(0.001)\end{array}$ & & \\
\hline PE & & & & & & & & & & & & & & & $\begin{array}{l}0.392 * * * \\
(0.000)\end{array}$ & \\
\hline PS & & & & & & & & & & & & & & & & $\begin{array}{l}-0.026^{*} \\
(0.070) \\
\end{array}$ \\
\hline Obs. & 994 & 994 & 994 & 994 & 993 & 994 & 994 & 994 & 992 & 945 & 993 & 500 & 1662 & 1427 & 1642 & 1658 \\
\hline $\begin{array}{l}\text { Wald } \\
\mathrm{Chi}^{2}\end{array}$ & $\begin{array}{l}142.76^{* * *} \\
(0.000)\end{array}$ & $\begin{array}{l}104.36^{* * * *} \\
(0.000)\end{array}$ & $\begin{array}{l}146.03 * * * \\
(0.000)\end{array}$ & $\begin{array}{l}150.06 \text { *** } \\
(0.000)\end{array}$ & $\begin{array}{l}146.32 * * * \\
(0.000)\end{array}$ & $\begin{array}{l}149.73 * * * \\
(0.000)\end{array}$ & $\begin{array}{l}139.53 * * * \\
(0.000)\end{array}$ & $\begin{array}{l}157.36^{* * *} \\
(0.000)\end{array}$ & $\begin{array}{l}135.94 * * * \\
(0.000)\end{array}$ & $\begin{array}{l}134.45 * * * \\
(0.000)\end{array}$ & $\begin{array}{l}226.42 * * * \\
(0.000)\end{array}$ & $\begin{array}{l}66.03 * * * \\
(0.000)\end{array}$ & $\begin{array}{l}455.00 * * * \\
(0.000)\end{array}$ & $\begin{array}{l}793.12 * * * \\
(0.000)\end{array}$ & $\begin{array}{l}963.72 * * * \\
(0.000)\end{array}$ & $\begin{array}{l}137.96 * * * \\
(0.000)\end{array}$ \\
\hline $\mathrm{m} 1$ & $\begin{array}{l}-2.017 * * \\
(0.043)\end{array}$ & $\begin{array}{l}-2.064 * * \\
(0.039)\end{array}$ & $\begin{array}{l}-2.250 * * \\
(0.024)\end{array}$ & $\begin{array}{l}-2.266^{* *} \\
(0.023)\end{array}$ & $\begin{array}{l}-1.741^{* *} \\
(0.041)\end{array}$ & $\begin{array}{l}-2.275^{* *} \\
(0.022)\end{array}$ & $\begin{array}{l}-2.158 * * \\
(0.030)\end{array}$ & $\begin{array}{l}-2.062 * * \\
(0.039)\end{array}$ & $\begin{array}{l}-2.323 * * \\
(0.020)\end{array}$ & $\begin{array}{l}-2.002 * * \\
(0.045)\end{array}$ & $\begin{array}{l}-2.048 * * \\
(0.040)\end{array}$ & $\begin{array}{l}-1.583^{* *} \\
(0.011)\end{array}$ & $\begin{array}{l}-2.262 * * \\
(0.023)\end{array}$ & $\begin{array}{l}-2.070 * * \\
(0.028)\end{array}$ & $\begin{array}{l}-1.554 * * \\
(0.012)\end{array}$ & $\begin{array}{l}-2.304 * * \\
(0.021)\end{array}$ \\
\hline $\mathrm{m} 2$ & $\begin{array}{l}-1.996 \\
(0.219) \\
\end{array}$ & $\begin{array}{l}-1.968 \\
(0.349) \\
\end{array}$ & $\begin{array}{l}-1.962 \\
(0.402) \\
\end{array}$ & $\begin{array}{l}-1.959 \\
(0.502)\end{array}$ & $\begin{array}{l}-1.231 \\
(0.202) \\
\end{array}$ & $\begin{array}{l}-1.963 \\
(0.432) \\
\end{array}$ & $\begin{array}{l}-1.976 \\
(0.345) \\
\end{array}$ & $\begin{array}{l}-1.349 \\
(0.329) \\
\end{array}$ & $\begin{array}{l}-1.548 \\
(0.108) \\
\end{array}$ & $\begin{array}{l}-1.903 \\
(0.198) \\
\end{array}$ & $\begin{array}{l}-1.496 \\
(0.138)\end{array}$ & $\begin{array}{l}-1.180 \\
(0.237) \\
\end{array}$ & $\begin{array}{l}0.248 \\
(0.803) \\
\end{array}$ & $\begin{array}{l}0.283 \\
(0.776) \\
\end{array}$ & $\begin{array}{l}0.571 \\
(0.567) \\
\end{array}$ & $\begin{array}{l}-1.869 \\
(0.821) \\
\end{array}$ \\
\hline
\end{tabular}

Note: Traditional home bias is dependent varable. Arellano-Bover/Blundell Bond Estimation with lags(1) and AR(2) tests. m1, m2: Arellano Bond test for no auto correlation. Lag value of traditional home bias is not 